\title{
A Review on Synthesis of Methane as a Pathway for Renewable Energy Storage With a Focus on Solid Oxide Electrolytic Cell-Based Processes
}

\author{
Saheli Biswas ${ }^{1}$, Aniruddha P. Kulkarni ${ }^{2 \star}$, Sarbjit Giddey ${ }^{2}$ and Sankar Bhattacharya ${ }^{1}$ \\ ${ }^{1}$ Department of Chemical Engineering, Monash University, Melbourne, VIC, Australia, ${ }^{2}$ CSIRO Energy, Clayton South, VIC, Australia
}

\section{OPEN ACCESS}

Edited by:

Valerie Eveloy,

Khalifa University,

United Arab Emirates

Reviewed by:

Søren Højgaard Jensen,

Aalborg University,

Denmark

Tong Liu,

Wuhan University, China

${ }^{*}$ Correspondence:

Aniruddha P. Kulkarni

Aniruddha.Kulkarni@csiro.au

Specialty section:

This article was submitted to Hydrogen

Storage and Production,

a section of the journal

Frontiers in Energy Research

Received: 06 June 2020

Accepted: 18 August 2020

Published: 08 September 2020

Citation:

Biswas S, Kulkarni AP, Giddey S and Bhattacharya S (2020) A Review on

Synthesis of Methane as a Pathway for

Renewable Energy Storage With

a Focus on Solid Oxide

Electrolytic Cell-Based Processes.

Front. Energy Res. 8:570112.

doi: 10.3389/fenrg.2020.570112
Environmental issues related to global warming are constantly pushing the fossil fuelbased energy sector toward an efficient and economically viable utilization of renewable energy. However, challenges related to renewable energy call for alternative routes of its conversion to fuels and chemicals by an emerging Power-to-X approach. Methane is one such high-valued fuel that can be produced through renewables-powered electrolytic routes. Such routes employ alkaline electrolyzers, proton exchange membrane electrolyzers, and solid oxide electrolyzers, commonly known as solid oxide electrolysis cells (SOECs). SOECs have the potential to utilize the waste heat generated from exothermic methanation reactions to reduce the expensive electrical energy input required for electrolysis. A further advantage of an SOEC lies in its capacity to coelectrolyze both steam and carbon dioxide as opposed to only water, and this inherent capability of an SOEC can be harnessed for in situ synthesis of methane within a single reactor. However, the concept of in situ methanation in SOECs is still at a nascent stage and requires significant advancements in SOEC materials, particularly in developing a cathode electrocatalyst that demonstrates activity toward both steam electrolysis and methanation reactions. Equally important is the appropriate reactor design along with optimization of cell operating conditions (temperature, pressure, and applied potential). This review elucidates those developments along with research and

\footnotetext{
Abbreviations: AEL, alkaline electrolytic cell; ASR, area-specific resistance; BOP, balance of plant; CCS, carbon capture and sequestration; DME, dimethyl ether; $\mathrm{e}^{-}$, electron; F, Faraday's constant $\left(96,485 \mathrm{C} \mathrm{mol}^{-1}\right)$; F-T, Fischer-Tropsch; $\Delta G$, Gibb's free energy $\left(\mathrm{kJ} \mathrm{mol}^{-1}\right) ; \Delta G^{0}$, Gibb's free energy at $298 \mathrm{~K}, 1 \mathrm{~atm}$; GDC, gadolinia-doped ceria; GHG, greenhouse gas; $\mathrm{H}^{+}$, hydrogen ion; $\Delta H$, change in enthalpy $\left(\mathrm{kJ} \mathrm{mol}^{-1}\right) ; \Delta H^{0}$, change in enthalpy at $298 \mathrm{~K}, 1 \mathrm{~atm} ; \mathrm{H}$-SOEC, proton-conducting solid oxide electrolytic cell; HT, high temperature; $I$, current (A); IEA, International Energy Agency; $K_{\text {eql }}$, equilibrium constant; $K_{\text {eql }}{ }^{0}$, equilibrium constant at $298 \mathrm{~K}, 1 \mathrm{~atm}$; LNG, liquefied natural gas; LSCF, strontium- and cobalt-doped lanthanum ferrite; LSCM, strontium- and cobalt-doped lanthanum manganite; LSMG, strontium- and magnesium-doped lanthanum gallate; LSF, strontium-doped lanthanum ferrite; LST, lanthanum-doped strontium titanate; LT, low temperature; MR, methanation reactor; $n$, number of electrons transferred during electrolysis; NEMCA, non-Faradaic electrochemical modification of catalytic activity; NTP, normal temperature and pressure of $298 \mathrm{~K}, 1 \mathrm{~atm} ; \mathrm{O}^{2-}$, oxide ion; $\mathrm{OH}^{-}$, hydroxyl ion; $\mathrm{P}$, partial pressure (atm); PEM, proton exchange membrane; $\mathrm{PV}$, photovoltaic; $R$, universal gas constant $\left(8.314 \mathrm{~J} \mathrm{~mol}^{-1} \mathrm{~K}\right) ; R_{\text {act }}$, resistance due to activation overpotential (ohm); $R_{\text {conv }}$, gas conversion overpotential $(\mathrm{ohm}) ; R_{\text {diff }}$ resistance due to diffusion overpotential $(\mathrm{ohm}) ; R_{\mathrm{ohm}}$, ohmic resistance $(\mathrm{ohm}) ; R_{\text {pol }}$, polarization resistance $(\mathrm{ohm}) ; \mathrm{R} \& \mathrm{D}$, research and development; RE, renewable energy; RTE, round trip efficiency; $\Delta S$, change in entropy $\left(\mathrm{kJ} \mathrm{mol}^{-1} \mathrm{~K}^{-1}\right) ; \Delta S^{0}$, change in entropy at $298 \mathrm{~K}, 1 \mathrm{~atm}\left(\mathrm{~kJ} \mathrm{~mol}^{-1} \mathrm{~K}^{-1}\right) ; \mathrm{ScSZ}$, scandia-stabilized zirconia; SDC, samaria-doped ceria; SOEC, solid oxide electrolytic cell; SR, Sabatier reactor; $T$, temperature $(\mathrm{K}) ; T^{0}$, normal temperature $(298 \mathrm{~K}) ; \mathrm{TPB}$, triple-phase boundary; $V_{0}$, minimum thermodynamic voltage required for electrolysis (V); $V_{n}$, Nernst potential (V); $V_{\mathrm{OP}}$, actual cell operating voltage (V); WGSR, water-gas shift reactor; X-ray near-edge structure, X-ray absorption near-edge structure; YSZ, yttria-stabilized zirconia; $\eta$, energy efficiency.
} 
development opportunities in this space. Also presented here is an efficiency comparison of different routes of synthetic methane production using SOECs in various modes, that is, as a source of hydrogen, syngas, and hydrogen/carbon dioxide mixture, and for in situ methane synthesis.

Keywords: renewable fuel, power-to-X, hydrogen, methane, solid oxide electrolyzer

\section{INTRODUCTION}

The global energy consumption has been increasing ever since the dawn of industrialization. Such an increase can be attributed to the expeditious economic growth across the globe and the rising population. World Energy Outlook 2019 [International Energy Agency (IEA) 2019 executive summary] and others (Criqui and Kouvaritakis, 2000; Newell et al., 2018) report that in 2018, worldwide energy consumption increased by $2.3 \%$, which is almost twice the average rate of growth since 2010. The deleterious aftermath of such higher energy consumption is an overall $\mathrm{CO}_{2}$ emission of $33.1 \mathrm{Gt}$, which is $1.7 \%$ higher than that in 2017. This is equivalent to $2.4 \mathrm{ppm}$ rise in the total concentration of atmospheric $\mathrm{CO}_{2}$ as stated by the IEA (Capuano, 2018) and others (Saracoglu et al., 2018). According to studies conducted by National Aeronautics and Space Administration (NASA) and recent UN reports, such a steady acceleration of $\mathrm{CO}_{2}$ levels will increase the earth's temperature by $1.5^{\circ} \mathrm{C}$ by 2052 , leading to the melting of the Arctic ice and subsequent perilous rise in sea level. Such effects coupled with the gradual depletion of fossil fuels has made a compelling case for the development and deployment of renewable energy (RE) sources such as solar, wind, tidal, and geothermal energy.

A substantial reduction in the manufacturing and capital costs associated with solar and wind energy plants has been observed in the last decade. Renewables 2018 (Saracoglu et al., 2018) predicts that by 2023 , there would be $1,460 \mathrm{TW}$ h of electricity generation from solar photovoltaic and 1,880 TW h of electricity generation from offshore and onshore wind turbines (Renewables, 2018). An analysis of the world energy scenario in terms of fuel type shows that consumption of renewables has expanded at an annual growth rate of about $12 \%$ over the past 10 years, driven by the move of electricity generation toward renewables (Tanaka, 2010).

Despite impressive numbers, inherent intermittency and uneven geographical distribution of RE sources remain a barrier for a solid commercial case of clean energy technologies, and therefore, reliance on fossil fuel continues. As such, the key enablers for renewable technology will be pathways for efficient and cost-effective storage as well as transportation of RE from the supply areas rich in RE to the demand areas like cities and industrial establishments. In this context, the conversion of RE into storable and transportable energy carriers is being considered a promising avenue to balance the energy supply-demand equation.

An emerging technology in this area is broadly defined as Power-to-X, where $\mathrm{X}$ can be a fuel such as hydrogen, ammonia, methanol, and dimethyl ether, or a commodity chemical like lubricants and aviation fuels (Foit et al., 2017; Rego de Vasconcelos and Lavoie, 2019; Dueñas et al., 2020). Hydrogen is a zero carbon-emission fuel with high gravimetric energy density $(33.3 \mathrm{~kW} \mathrm{~h} / \mathrm{kg})$ that can be synthesized using various electrolytic, photocatalytic, or solar thermochemical processes (Chen and Shangguan, 2013; Acar and Dincer, 2019) and can be efficiently converted back to energy without carbon emission. However, the major hurdles in a hydrogen-based RE economy are difficulties in the storage and transportation of hydrogen owing to energyintensive processes of compression or liquefaction and boil-off losses during transportation. For instance, up to $12 \%$ of the energy content of hydrogen is lost while compressing the gas to the required pressures (Makridis, 2017; Bruce et al., 2018). Although hydrogen has a very high gravimetric heat content (lower heating value (LHV) of $33.3 \mathrm{kWh} / \mathrm{kg}$ ), its volumetric heat content is very low $(2.73 \mathrm{Wh} / \mathrm{L})$. Further, several challenges related to the mechanical properties of storage materials need to be addressed (Christian et al., 2013; Prabhukhot Prachi et al., 2016).

A last link of the supply chain technology is the conversion of hydrogen back to energy that also needs substantial bottoms-up development. Most of the current infrastructure for utilization of carbon fuels such as gasoline, diesel, or natural gas cannot be used with hydrogen in high concentration due to issues related to hydrogen embrittlement, flame travel distance, and a high autoignition temperature (Verhelst and Wallner, 2009).

In response to these challenges, storing and transporting energy in the form of hydrogen carriers appears interesting, where methane is being considered one of the promising and practical energy cum hydrogen carriers due to its moderately high heat content (LHV of $13 \mathrm{~kW} \mathrm{~h} / \mathrm{kg}$ ) as compared to other prospective alternatives such as gasoline (LHV of $12 \mathrm{~kW} \mathrm{h/kg}$ ) and ammonia (LHV of $5.2 \mathrm{~kW} \mathrm{h/kg}$ ), lower compression energy $(0.56 \mathrm{~kW} \mathrm{~h} / \mathrm{kg}$ at the usual compression pressure of $350 \mathrm{bar})$ (Makridis, 2017), and facile synthesis using RE and waste $\mathrm{CO}_{2}$ (Figure 1A).

Methane is a primary constituent of natural gas (50-90\%) and can be effectively used for any application where natural gas is being currently used. Apart from this, methane finds potential application in different chemicals production as well. Global Energy Statistical Yearbook states that from 2010 to 2018, global natural gas consumption increased by $11 \%$, and the IEA has predicted that this value will rise to almost $55 \%$ with a total gas consumption of 253,330 TW h by 2040 (Capuano, 2018). Recently, there has been an interest in utilizing methane as a probable RE carrier, especially in the context of Australia's abundant RE potential and its vision as an exporter of the same to other countries.

Several processes to produce methane from feedstock (typically $\mathrm{CO}_{2}$ and $\mathrm{H}_{2}$ ) are under investigation. These include thermochemical (Mills and Steffgen, 1974; Anderson et al., 1984; Schulz, 1999; Junaedi et al., 2014; El Sibai et al., 2015), photocatalytic (Kondratenko et al., 2013; Wang K. et al., 2017; 

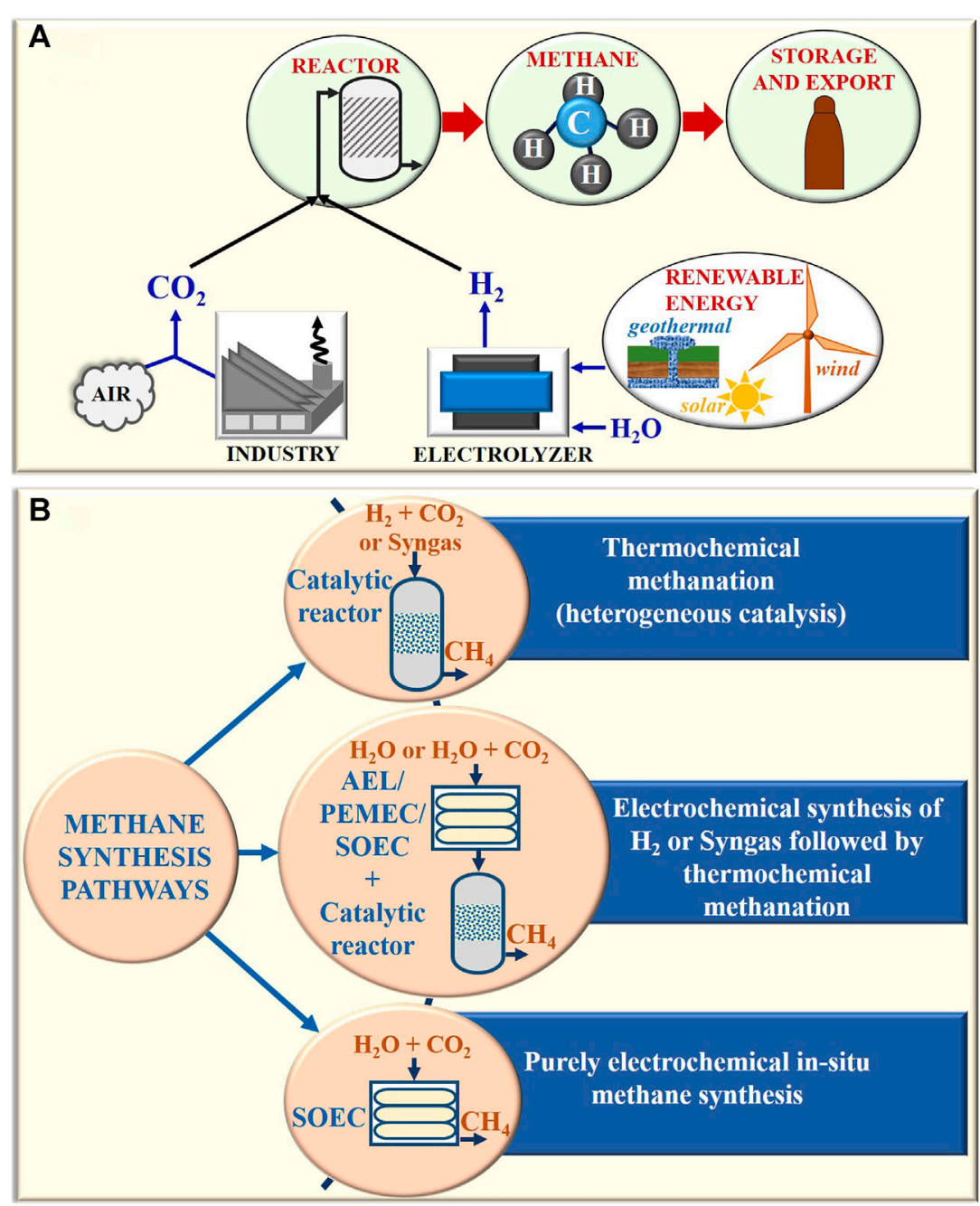

FIGURE 1 | A) Methane synthesis through renewables-powered electrochemical reactors. (B) Three major pathways of methane synthesis.

Murugesan et al., 2020), electrochemical (Kondratenko et al., 2013; Clausen et al., 2019; Kofler et al., 2019), and biogenic (Hobson et al., 1981; Cimon et al., 2020) routes. Among these, thermochemical methanation is perhaps the most extensively studied and currently used for synthetic methane manufacturing. The process can utilize hydrogen generated non-renewably through natural gas and oil reforming processes, or renewably by electrolysis, photocatalysis, plasma reforming, thermochemical water splitting, dark fermentation, and biophotolysis (Acar and Dincer, 2019). The hydrogen production technologies have been presented in the literature in great depths, with a plethora of reviews on materials, methods, and techno-economics thereof (Nikolaidis and Poullikkas, 2017; Acar and Dincer, 2019; Zhu et al., 2019).

In the genre of electrolytic routes, a comparatively early-stage technology that offers scalable, economic, and highly efficient solution to produce either pure hydrogen or syngas (a mixture of $\mathrm{CO}$ and $\mathrm{H}_{2}$ ) for methanation is based upon solid oxide electrolysis. More interestingly, it can be used to directly synthesize methane from steam and $\mathrm{CO}_{2}$ co-electrolysis with a right combination of electrocatalyst and process conditions. However, this route of methane synthesis is not yet well established, with a dearth of knowledge on the fundamental mechanism, reaction pathways, and development of materials tailored to improve the reaction kinetics, product selectivity, and process efficiency. Further, the scale and lifetime of solid oxide electrolyzers remain limited compared to those of more established alkaline and proton exchange membrane (PEM) electrolyzers.

For methane synthesis using solid oxide electrolytic cell (SOEC) coupled with a thermochemical methanator, the challenges are essentially those related to hydrogen and syngas production in SOECs. This review elucidates those issues followed by a brief discussion on the emerging area of one-step methane generation in SOEC via co-electrolysis of steam (instead of hydrogen) and $\mathrm{CO}_{2}$. An efficiency comparison of methane synthesis using SOEC in all possible configurations has also been presented at the end. For such comparison, previous studies (Jensen et al., 2015; Luo et al., 2018; Wang et al., 2018; Wang L. et al., 2019) have focused on SOECs 
only as a source of hydrogen and syngas $\left(\mathrm{H}_{2} / \mathrm{CO}\right)$, but here we have considered SOECs as a source of $\mathrm{H}_{2} / \mathrm{CO}_{2}$ mixture and for in situ methanation as well.

\section{MAJOR PATHWAYS OF METHANE SYNTHESIS}

As opposed to other emerging hydrogen carriers, the infrastructure for the synthesis, storage, transport, and utilization of methane is fairly well-established. Several pathways of methane synthesis have emerged over the past few decades that can be broadly categorized as shown in Figure 1B and have been briefly described in this review with a detailed discussion on SOECs. Synthetic methane production routes can be classified as follows:

(1) Purely thermochemical process in a catalytic reactor using biosyngas or industrial syngas, or other non-electrolytic sources of $\mathrm{H}_{2}$ and $\mathrm{CO}_{2}$ (discussed in Purely Thermochemical Route of Methane Synthesis)

(2) Combined thermo-electro-chemical process where $\mathrm{H}_{2}$ produced from electrolytic routes [using alkaline electrolytic cells (AELs) or PEM electrolytic cells (PEMECs) or solid oxide electrolytic cells (SOECs)] or syngas produced from steam $/ \mathrm{CO}_{2}$ co-electrolysis in SOECs is utilized for thermochemical methanation in a conventional catalytic reactor (discussed in Combined Thermo-ElectroChemical Route of Methane Synthesis and Challenges and Advancement in the Electrolytic Production of Hydrogen and Syngas in Solid Oxide Electrolytic Cell Integrated With Thermochemical Reactor for Methane Synthesis)

(3) Purely electrochemical process of in situ methane synthesis in high-temperature SOECs (discussed in State of the Art of Purely Electrochemical In Situ Methane Synthesis in Solid Oxide Electrolytic Cell)

As can be well perceived from the above classifications, synthetic methane production requires a source of carbon along with an electrolytic or non-electrolytic source of hydrogen. Several industrial processes yield highly pure and concentrated $\mathrm{CO}_{2}$ off-gas, which can be separated from impurities and sequestered (Farla et al., 1995). These processes include production of alcohols (ethanol and methanol), ammonia synthesis, synthetic fuel production, and production of several organic chemicals. Other sources of $\mathrm{CO}_{2}$ in high concentration include iron and steel plants (Kim and Worrell, 2002) and cement industries (Taylor et al., 2006). Process heaters, fluidized catalytic cracking units, and steam methane reforming of hydrogen production units in refineries (Van Straelen et al., 2010) are also important sources of $\mathrm{CO}_{2}$.

A naïve yet promising process for producing $\mathrm{CO}_{2}$ is direct air capture, which is an industrial process of trapping $\mathrm{CO}_{2}$ from the ambience with subsequent conversion to pure $\mathrm{CO}_{2}$ stream that can be either sequestered or recycled back for other industrial processes (Figure 2). Processes available for this emerging technology include absorption of $\mathrm{CO}_{2}$ by ion exchange membranes with humidity-swing regeneration (Lackner, 2003), solid amines on a mesoporous silica substrate (Gray et al., 2008), and alkaline aqueous solution (Keith, 2009).

\section{PURELY THERMOCHEMICAL ROUTE OF METHANE SYNTHESIS}

Most of the current industrial applications of methane are essentially in petroleum or natural gas markets, and as such, synthetic methanation is limited to removal of $\mathrm{CO}_{2}$ and $\mathrm{CO}$ during steam methane reforming in processes such as ammonia production. Typically, methanation is carried out in a thermochemical catalytic reactor in the temperature range of $250-350^{\circ} \mathrm{C}$ and 25 bar pressure by either $\mathrm{CO}_{2}$ hydrogenation (Mills and Steffgen, 1974; Wei and Jinlong, 2011; Junaedi et al., 2014; El Sibai et al., 2015) via the Sabatier process (Eq. 1) or CO hydrogenation (Anderson et al., 1984; Schulz, 1999; Van Der Laan and Beenackers, 1999; Méndez and Ancheyta, 2020) via the Fischer-Tropsch process (Eq. 2). Reaction kinetics and product selectivity are heavily affected by the type of catalyst and support, whereas overall reactor efficiency depends on its design and operating conditions, all of which have been widely studied till date and are not within the scope of our present discussion, and readers are referred to reviews and books (Mills and Steffgen, 1974; Rönsch et al., 2016; Mebrahtu et al., 2019).

Both $\mathrm{CO}_{2}$ and $\mathrm{CO}$ methanation are highly exothermic reactions accompanied by a reduction in volume, thus favorable at high pressures and low temperatures (LTs).

$$
\begin{gathered}
\mathrm{CO}_{2}+4 \mathrm{H}_{2}=\mathrm{CH}_{4}+2 \mathrm{H}_{2} \mathrm{O}\left(\Delta \mathrm{H}_{1,023 \mathrm{~K}}=-164 \mathrm{~kJ} \mathrm{~mol}^{-1}\right) \\
\mathrm{CO}+3 \mathrm{H}_{2}=\mathrm{CH}_{4}+\mathrm{H}_{2} \mathrm{O}\left(\Delta \mathrm{H}_{1,023 \mathrm{~K}}=-206.1 \mathrm{~kJ} \mathrm{~mol}^{-1}\right) \\
\mathrm{CO}_{2}+\mathrm{H}_{2}=\mathrm{CO}+\mathrm{H}_{2} \mathrm{O}\left(\Delta \mathrm{H}_{1,023 \mathrm{~K}}=41.2 \mathrm{~kJ} \mathrm{~mol}^{-1}\right)
\end{gathered}
$$

As can be determined from Eqs 1 and 2, the stoichiometric methanation of $\mathrm{CO}_{2}$ and $\mathrm{CO}$ is accompanied by the evolution of 2.03 and $2.55 \mathrm{~kW} \mathrm{~h}$ heat per cubic meter of methane produced at normal temperature and pressure of $298 \mathrm{~K}$.

The thermodynamics and kinetics of both $\mathrm{CO}$ and $\mathrm{CO}_{2}$ methanation processes have been widely studied by many

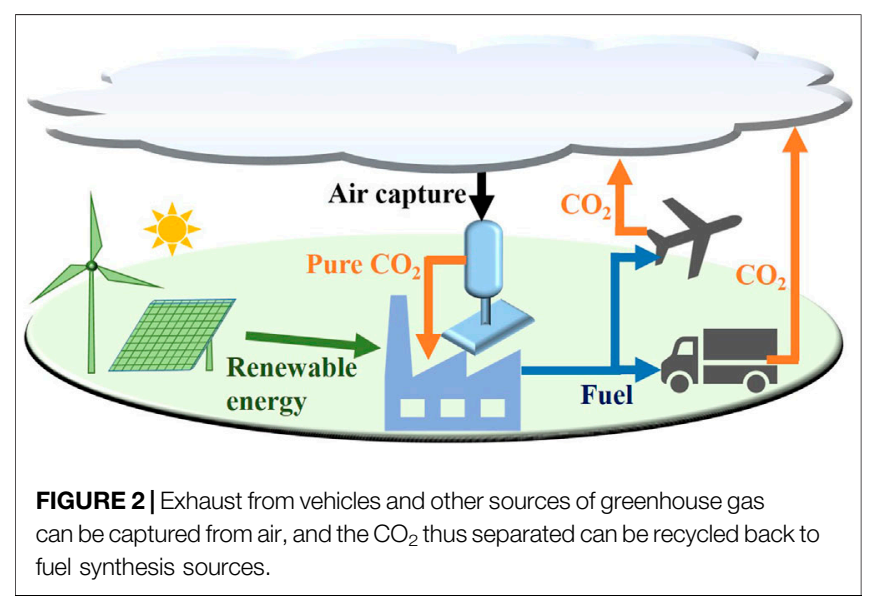


researchers (Gao et al., 2012; Sahebdelfar and Takht Ravanchi, 2015; Rönsch et al., 2016). As reported by Gao et al. (2012), a maximum yield of $\mathrm{CH}_{4}(>90 \%)$ from $\mathrm{CO}$ methanation is obtained in the temperature range of $200-300^{\circ} \mathrm{C}$. In case of the Sabatier reaction as well, methane yield maintains a steady value (>90\%) for temperatures up to $300^{\circ} \mathrm{C}$, irrespective of pressure. Above $450^{\circ} \mathrm{C}$, the reverse water gas shift (RWGS) reaction (Eq. 3) becomes dominant due to its endothermic nature and results in an upsurge of the $\mathrm{CO}$ by-product with a commensurate decrease in methane yield. Thus, the overall process of $\mathrm{CO}_{2}$ conversion is dictated by competing reactions 1 and 3 .

A perfect combination of LT, high pressure, appropriate $\mathrm{H}_{2}: \mathrm{CO}_{2}$ ratio, and suitable catalyst plays an important role for maximum methane yield from the Sabatier reaction. Compared to $\mathrm{CO}_{2}, \mathrm{CO}$ hydrogenation is more exothermic and releases $3.58 \mathrm{MW} h$ heat for each ton of methane produced, and reaction kinetics is also expected to be faster as the reactivity of $\mathrm{CO}$ is likely to be higher than that of $\mathrm{CO}_{2}$ molecule. Thus, methane synthesis from renewably produced syngas might be a better option instead of $\mathrm{CO}_{2}$ hydrogenation with only hydrogen produced renewably (Sabatier process), as further discussed in Energy Efficiency of Methane Synthesis via Different Electrochemical Routes.

\section{COMBINED THERMO-ELECTRO-CHEMICAL ROUTE OF METHANE SYNTHESIS}

Green hydrogen generation for synthetic methane production has been widely studied using different electrolysis cells or electrolyzers that have been developed over the past few decades. These electrolyzers can be classified based upon the type of electrolyte (aqueous or solid) and ionic species transported during electrolysis, and operating temperature regimes as shown in Figures 3A,B. The aqueous solutionbased electrolytes were the original choice for electrolytes, and the most technologically matured electrolyzer design, AEL is based upon an aqueous electrolyte which transports hydroxyl ions $\left(\mathrm{OH}^{-}\right)$. Further, the family of electrolyzers based upon solid membrane electrolytes emerged where electrolytes are nonporous solids, which can either be proton $\left(\mathrm{H}^{+}\right)$or oxide ion $\left(\mathrm{O}^{2-}\right)$ conductors. This group of electrolyzers can operate over a wide range of temperature and can be broadly classified into low temperature $\left(\mathrm{LT} ; \quad<100^{\circ} \mathrm{C}\right)$, intermediate temperature $\left(100-500^{\circ} \mathrm{C}\right)$, and high temperature $\left(\mathrm{HT} ;>500^{\circ} \mathrm{C}\right)$. In addition to these common types, electrolyzers based upon molten carbonate electrolytes have been evaluated to some extent

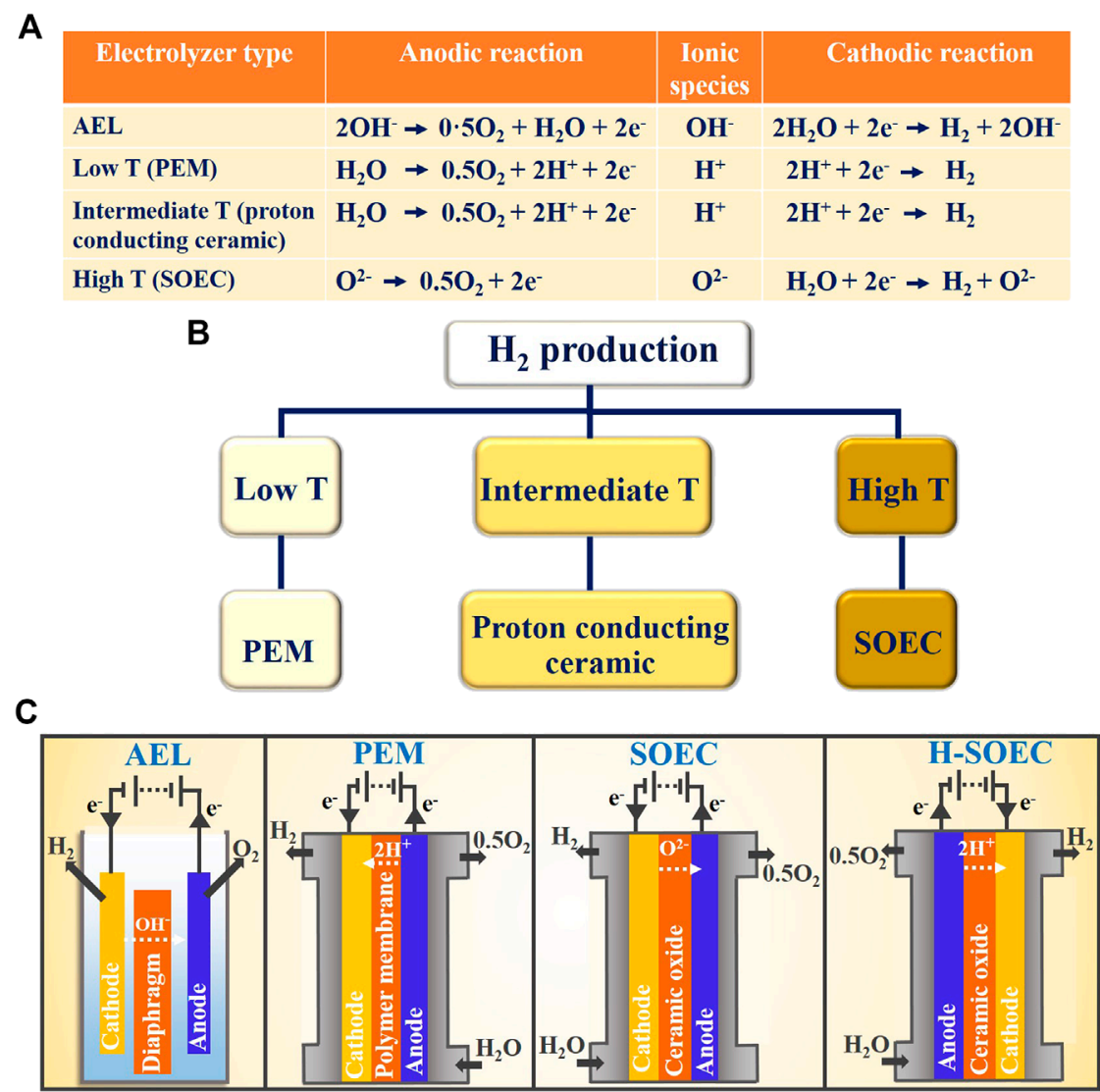

FIGURE 3 |A) lonic species for different types of electrolyzers. (B) Temperature-based classification of electrolyzers used for solid electrolytic routes of hydrogen synthesis. (C) Basic working principle of alkaline electrolytic cells, proton exchange membrane, solid oxide electrolytic cells, and proton-conducting solid oxide electrolytic cells. 
where the electrolyte is a molten carbonate material which operates at temperatures above $600^{\circ} \mathrm{C}(\mathrm{Hu}, 2016$; Hu et al., 2016).

PEMECs are most widely used for LT operation. Polymer composite electrolyte membranes, beta alumina-based electrolyte membranes, and proton-conducting solid oxide electrolytic cells (H-SOECs) are used for intermediate temperature range and emerging solid oxide electrolytic cells (SOECs) used for HT operation (Figure 3B). The basic working principles of AELs, PEMECs, SOECs, and H-SOECs are depicted in Figure $3 \mathrm{C}$. Each of these electrolyte systems is at a different stage of technological maturity and comes with its own merits and demerits as discussed in reviews (Carmo et al., 2013; Santos et al., 2013; Rashid et al., 2015). In the section below, we have briefly discussed AEL and PEM technology followed by a detailed discussion on SOEC technology.

\section{Alkaline Electrolyzer}

AELs have existed ever since the dawn of electrolysis and witnessed remarkable improvements over many decades, which make AELs suitable for large-scale hydrogen production with capacities as high as $500-760 \mathrm{Nm}^{3} / \mathrm{h}$ (Vandenborre et al., 1980; Vermeiren et al., 1998; Ulleberg, 2003; Ursua et al., 2012).

The setup is relatively simple with two electrodes, usually a mild steel cathode and an $\mathrm{Ni}$ anode immersed in a liquid alkaline electrolyte (20-30\% potassium hydroxide, $\mathrm{KOH}$ ), and separated by a porous diaphragm permeable to both $\mathrm{OH}^{-}$ions and water molecules. The operating temperature of AELs varies from 70 to $90^{\circ} \mathrm{C}$, and hydrogen can be produced at pressures from 1 to $30 \mathrm{bar}$ (Ursua et al., 2012). However, few of the shortcomings of AELs include corrosiveness of the electrolyte that reduces cell lifetime, and a low current density $\left(100-300 \mathrm{~mA}\right.$ per $\mathrm{cm}^{2}$ of the electrode area) due to high ohmic losses which increase plant footprint (Mazloomi and Sulaiman, 2012). Current density is an important figure of merit used for comparison of the electrolytic systems as it is directly proportional to the rate of hydrogen production. More importantly, the limited ability of AELs for dynamic response to the fluctuations in the electricity supply is a key issue when it is powered by RE sources like solar and wind, which are intermittent in nature. Any additional requirement for energy storage devices such as batteries and related electronics significantly increases the capital and process costs, leading to an increased levelized cost of hydrogen production. Some opportunities for further improvement of this electrolyzer are in the improvement of diaphragm materials and electrocatalysts.

\section{Proton Exchange Membrane Electrolyzer}

To overcome the limitations of AELs, the concept of replacing the electrolytic solution by a solid polymeric membrane having proton conductivity emerged, and the electrolyzer came to be known as PEMEC, more popularly PEM (Xu and Scott, 2010; Carmo et al., 2013; Paidar et al., 2016; Jayakumar, 2019; Yang et al., 2019). In PEM electrolyzers, oxygen is released at the anode, and the $\mathrm{H}^{+}$ions migrate to the cathode through the solid nonporous polymeric membrane, where they recombine with $\mathrm{e}^{-}$to release hydrogen gas. As the anode and cathode are separated by the polymeric electrolyte membrane, this guarantees minimum gas crossover with the yield of very high purity hydrogen. The most commonly used polymer membrane electrolyte material is Nafion sold by Dupont Ltd. On the anode side, a titanium (Ti)-based electrode mesh or foam with iridium (Ir)-based oxygen evolution electrocatalyst is used, and on the cathode side, platinum $(\mathrm{Pt})$ metal nanoparticles supported on a high surface area carbon support are used. With improvements in design and materials, the PEM technology has made substantial progress, and the operating current densities can be as high as $1.5 \mathrm{~A} \mathrm{~cm}^{-2}$ and hydrogen can be produced at pressures above $30 \mathrm{bar}$ (Ayers et al., 2010). The design of PEM is relatively compact and modular in nature, allowing for flexibility in scale and configuration of the system. Considerable progress has been made over the past decade in terms of technological maturity with systems up to $3 \mathrm{MW}$ scale available commercially. Despite such progress, key technical challenges still remain unsolved, which include high costs associated with components fabrication, reliance on precious metal group catalysts, and performance degradation over the lifetime requiring incremental electrical energy input.

The levelized cost of hydrogen production per kilogram by PEM is in the range of \$ 6.08-7.43 and for AEL, about \$4.78-5.84 (Bruce et al., 2018). These costs are expected to decrease as the scale of the system increases. The cost of hydrogen from electrolysis is somewhat challenging considering the variables involved; however, it is generally agreed that cost of electricity is a major contributor with up to $65 \%$ of the cost of hydrogen (James et al., 2016; McDonagh et al., 2018). Clearly, the reduction in electrical energy input and lower cost of electricity can bring a shift change in the cost of electrolysis.

The minimum theoretical energy required for water electrolysis with PEM or AEM is about $40 \mathrm{kWh} / \mathrm{kg}$ of hydrogen. On top of that, losses associated with electrolyte resistance and electrode reactions (electrode polarization) and system-level losses add up. The total energy required at the system level can be as high as $5 \mathrm{~kW} \mathrm{~h}$ per $\mathrm{Nm}^{3}$ of hydrogen, which equates to about a whopping $60 \mathrm{~kW} \mathrm{~h} / \mathrm{kg}$ of hydrogen.

SOECs have a great potential to overcome the limitations of AELs and PEM, in particular energy requirements (Luo et al., 2018; Wang L. et al., 2019). Further, it allows electrolysis of not only water but also $\mathrm{CO}_{2}$ and co-electrolysis of steam $/ \mathrm{CO}_{2}$ mixture (Bandi et al., 1995; Laguna-Bercero, 2012; Hansen, 2015; Zheng et al., 2017). SOEC operation at HTs (above $600^{\circ} \mathrm{C}$ ) requires a substantially lower electric energy input per kilogram of fuel produced due to favorable cell thermodynamics, which has been elaborated in a subsequent section. A detailed comparison of the characteristics of AELs, PEMECs, and SOECs is available in the literature (Bertuccioli et al., 2014; Bhandari et al., 2014; Peterson and Miller, 2016; Schmidt et al., 2017; Buttler and Spliethoff, 2018).

\section{BASIC WORKING PRINCIPLE OF SOLID OXIDE ELECTROLYTIC CELLS AND THEIR APPLICATION IN SYNTHETIC METHANE PRODUCTION}

Figure 4A shows the basic working principle of SOECs. The electrodes are separated by a dense ion-conducting ceramic 
membrane. The feed gases, that is, steam or $\mathrm{CO}_{2}$ or both, are supplied to the cathode where it reacts with electrons provided by an external power supply to produce $\mathrm{H}_{2}$ and $\mathrm{CO}$, respectively, and oxygen ions, which are transported through an ionconducting electrolyte to the anode, where they combine and release the electrons $\left(\mathrm{e}^{-}\right)$again (Bandi et al., 1995; Zheng et al., 2017; Pandiyan et al., 2019). The electrochemical reactions taking place in the SOECs are given as follows:

Cathode

i. Steam electrolysis:

$$
\mathrm{H}_{2} \mathrm{O}+2 \mathrm{e}^{-} \rightarrow \mathrm{H}_{2}+\mathrm{O}^{2-}\left(\Delta \mathrm{H}_{1,023 \mathrm{~K}}=241 \mathrm{~kJ} \mathrm{~mol}^{-1}\right)
$$

ii. $\mathrm{CO}_{2}$ electrolysis:

$$
\mathrm{CO}_{2}+2 \mathrm{e}^{-} \rightarrow \mathrm{CO}+\mathrm{O}^{2-}\left(\Delta \mathrm{H}_{1,023 \mathrm{~K}}=282.5 \mathrm{~kJ} \mathrm{~mol}^{-1}\right)
$$

iii. Steam $/ \mathrm{CO}_{2}$ co-electrolysis:

$$
\begin{aligned}
\mathrm{CO}_{2}+\mathrm{H}_{2} \mathrm{O}+4 \mathrm{e}^{-} \rightarrow & \mathrm{CO}+\mathrm{H}_{2}+2 \mathrm{O}^{2-}\left(\Delta \mathrm{H}_{1,023 \mathrm{~K}}\right. \\
& \left.=523.5 \mathrm{~kJ} \mathrm{~mol}^{-1}\right)
\end{aligned}
$$

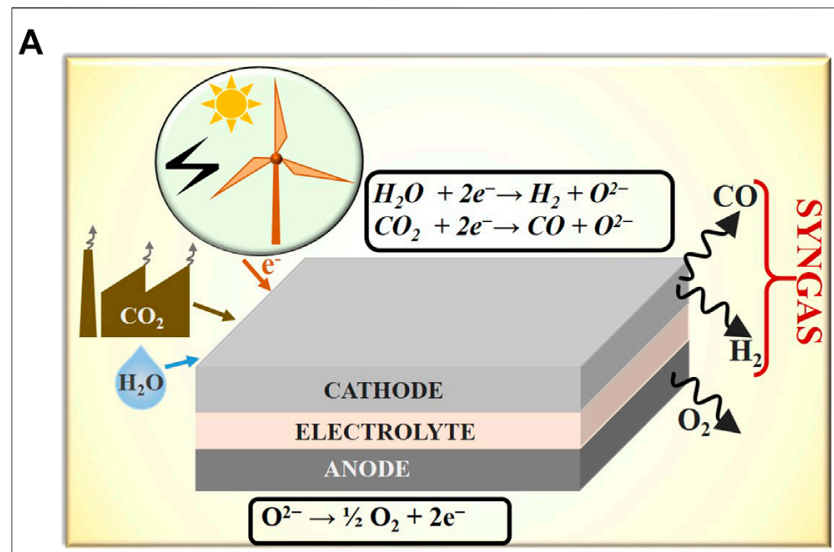

B

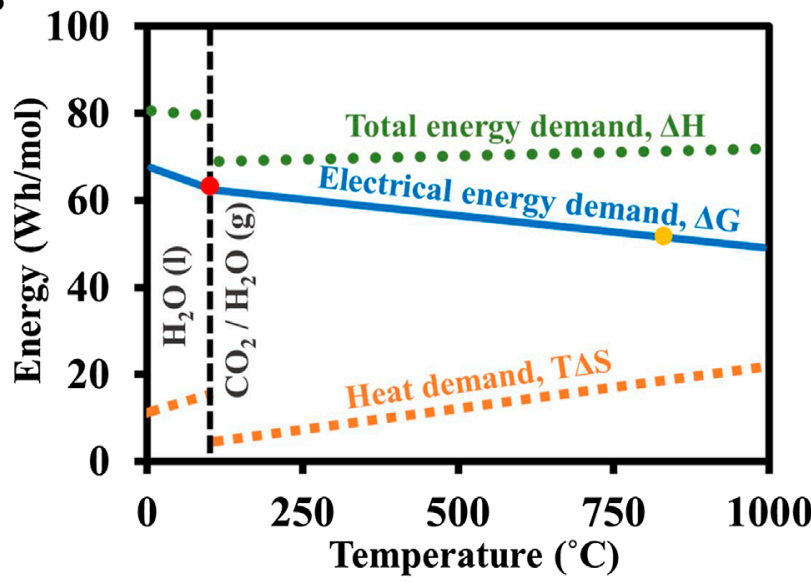

FIGURE 4 | A) Primary reactions taking place in a SOEC during $\mathrm{H}_{2} \mathrm{O}$ / $\mathrm{CO}_{2}$ co-electrolysis. (B) $\Delta H, \Delta G$, and $T \Delta S$ of steam $/ \mathrm{CO}_{2}$ splitting as a function of temperature. The red and yellow dots denote the typical operating temperature of a standard alkaline electrolytic cells/proton exchange membrane and SOEC.
Anode

$$
\text { Oxygen evolution: } \mathrm{O}^{2^{-}} \rightarrow 1 / 2 \mathrm{O}_{2}+2 \mathrm{e}^{-}
$$

The voltage gradient across the ion-conducting membrane drives the reaction, and the minimum operating voltage $\left(V_{0}\right)$ required for the process is equal to the change in the Gibbs free energy $(\Delta G)$ :

$$
\Delta G=\Delta H-T \Delta S,
$$

where $\Delta H$ is the enthalpy change given by the heat of the reaction and $T \Delta S$ is the supply of external heat, $T$ being the temperature and $\Delta S$ the entropy change.

As can be forecasted from Eq. 8, with an increase in $T, \Delta H$ remains almost unaffected, while $\Delta G$ (electrical energy input) decreases almost linearly with $T$ (Figure 4B) since both steam and $\mathrm{CO}_{2}$ decomposition are highly endothermic reactions (Eqs 4 and 5). Hansen (2015) reported that the ratio of $\Delta G$ to $\Delta H$ is about $93 \%$ at $80^{\circ} \mathrm{C}$ and about $77 \%$ at $750^{\circ} \mathrm{C}$. This reduction in $\Delta G$ is significant, as it constitutes over $64 \%$ of the total cost of electrolytic hydrogen production, as discussed earlier. More importantly, the heat $(T \Delta S)$ can be sourced either as low-grade waste heat from industrial processes, or as high-grade heat from the solar thermal concentrators.

The operating voltage of the cell is governed by its ohmic resistance and resistances offered by the activation of electrodes, charge transfer, diffusion of the reactant and the product gases, and gas conversion. All these resistances together are often referred to as area-specific resistance of the cell and dictate the efficiency and, in turn, the cost of fuel production.

\section{Solid Oxide Electrolytic Cell Materials, Designs, and Modes of Operation for Methane Synthesis}

The solid oxide electrolyte in SOECs can be either an oxygen ion conductor or a proton conductor. A major development of SOECs revolves around oxygen ion-conducting electrolytes, but there has been renewed interest in proton-conducting electrolytes for SOEC application (Ding et al., 2019; Duan et al., 2019; Vøllestad et al., 2019). Despite the impressive performance, H-SOECs are still at infancy and limited to the laboratory scale relative to the oxygen ion conductor-based technology.

Most of the materials and methods of fabrication for SOECs are derived from those used for solid oxide fuel cells (SOFCs), which is already a commercialized technology. For state-of-theart SOECs, choice of the electrolyte is an oxygen ion-conducting ceramic known as $8 \mathrm{~mol} \%$ yttria $\left(\mathrm{Y}_{2} \mathrm{O}_{3}\right)$-stabilized zirconia $\left(\mathrm{ZrO}_{2}\right)$ or YSZ (Smart and Weissbart, 1967; Bandi et al., 1995; Graves et al., 2011). As shown in Figure 4A, the electrolyte is sandwiched between the fuel electrode (cathode) and the oxygen electrode (anode). Cathodes are generally composed of porous composites (commonly known as cermets) of Ni metal with YSZ, which is made by mixing $\mathrm{NiO}$ with YSZ. The state-of-the-art anode (oxygen evolution electrode) materials for SOECs are lanthanum strontium manganite $\left(\mathrm{La}_{0.8} \mathrm{Sr}_{0.2} \mathrm{MnO}_{3-\delta}\right.$, commonly known as LSM) and YSZ composite (Kim et al., 2001; Chen et al., 
2004; Murakami et al., 2010; Kaur et al., 2018b), or lanthanum strontium cobalt ferrite $\left(\mathrm{La}_{0.8} \mathrm{Sr}_{0.2} \mathrm{Co}_{0.2} \mathrm{Fe}_{0.8} \mathrm{O}_{3 \delta}\right.$, commonly known as LSCF) (Laguna-Bercero et al., 2011; Zheng et al., 2014). Several new materials are being developed and trialed as SOEC electrodes such as mixed conductor perovskites (Ebbesen and Mogensen, 2009; Laguna-Bercero, 2012). In particular, there has been significant research on new cathode materials (Wang Y. et al., 2017) with regard to methanation, as discussed in Challenges and Advancement in the Electrolytic Production of Hydrogen and Syngas in Solid Oxide Electrolytic Cell Integrated With Thermochemical Reactor for Methane Synthesis.

SOECs can be fabricated in two different configurations, namely, planar and tubular (Shi et al., 2015), as shown in Figures 5A,B. Planar cells are in the form of square or rectangular flat plates or circular discs (Figure 5A) that can be stacked on top of one another and interconnected in series with metallic or ceramic plates referred to as interconnects, which are electronic conductors in both reducing and oxidizing atmospheres. The planar cells can either be electrode supported (Knibbe et al., 2010) where the anode is first prepared followed by casting a thinner layer of electrolyte atop (Figure 5C), or electrolyte supported (Ursua et al., 2012; Ghaib and Ben-Fares, 2018) where the electrolyte is first fabricated followed by electrode coating (Figure 5D). In electrodesupported cells, the electrolyte is few microns thick, which remarkably reduces the ohmic resistance. However, such thin electrolytes are vulnerable to mechanical stresses and prone to failure under continually variable loading conditions which are common with renewables. Another design under consideration is a metal-supported cell where a porous metallic plate acts as a

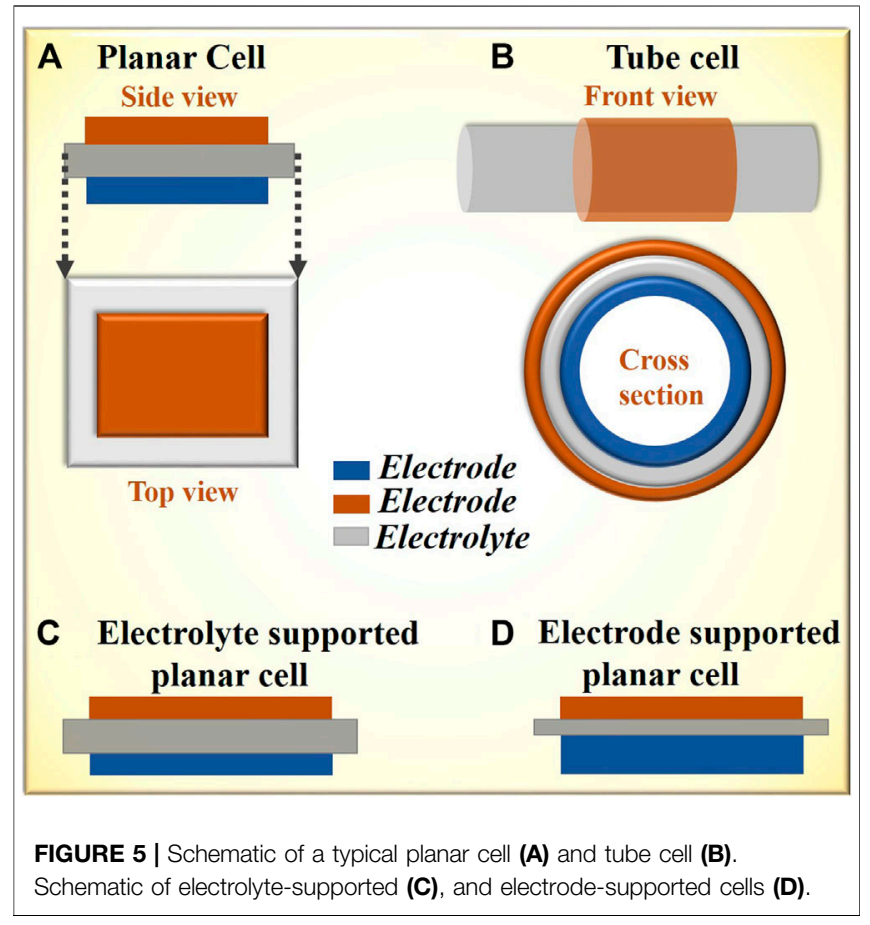

support and very thin layers of electrode and electrolyte can be coated on it (Tucker, 2010; Leah et al., 2017).

The planar design ensures high volumetric hydrogen production and a facile fabrication process. However, major concerns include issues with the hermetic sealing required to separate fuel gas from the air and compressive stresses lowering the ability of stack to cope up with thermal cycling.

Alternatively, a tubular design (Figure 5B) is available, where either an electrolyte or a cathode (fuel electrode) is formed in the shape of a tube, typically by processes such as isostatic bag pressing, extrusion, or freeze casting. Once the starting component is prepared, the remaining electrodes/electrolytes can be coated by a variety of processes, including dip coating, spray coating, or brush painting. The tubular cells are freestanding and can be stacked side by side in a row or as a bundle of several tubes. In the case of electrolyte-supported tubular cells, the requirements for sealing are less stringent, and the ability to cope with thermal cycling is shown to be better (Kaur et al., 2018a). The downsides of this tubular geometry are a lower volumetric current density leading to a larger footprint of the system and issues with designing and fabrication of current collectors for current collection from the tube interior.

SOECs can be operated in four different modes or configurations for methane synthesis as shown in Table 1. The first two modes belong to thermo-electro-chemical routes of methane synthesis, whereas modes 3 and 4 constitute purely electrochemical pathways (Figure 1B). In modes 1 and 2, SOECs simply act as a source of hydrogen or syngas coupled with a separate conventional SR or methanation reactor (MR), respectively, whereas modes 3 and 4 encompass methanation carried out in a single reactor without the need for a separate downstream process. The differences between modes 3 and 4 are the operating temperature and role of cathode toward the entire process. In mode 3 , the cathode itself acts as a methanation catalyst, or the catalyst is in direct physical contact with the cathode, referred to as bilayer electrodes. With bilayer cathodes, both steam $/ \mathrm{CO}_{2}$ co-electrolysis and methanation occur on the

TABLE 1 | Different modes of operation of SOECs for methane synthesis.

\section{Mode Process description}

Mode 1 SOEC supplies hydrogen produced by steam electrolysis to a conventional Sabatier reactor. Heat from the Sabatier reactor can be used for the SOEC reactor (i.e., steam production and maintaining temperature).

Mode 2 SOEC supplies syngas produced by steam $/ \mathrm{CO}_{2}$ electrolysis to a conventional methanation reactor. Heat from the methanation reactor can be used for the SOEC reactor (i.e., steam production, heating reactant gases, and maintaining temperature).

Mode 3 In situ methanation in a single temperature zone cell where both steam $/ \mathrm{CO}_{2}$ co-electrolysis and methanation occur on the cathode itself. One-step process without a downstream reactor.

Mode $4 \quad$ In situ methanation in a dual temperature zone cell where syngas generation from steam $/ \mathrm{CO}_{2}$ co-electrolysis occurs on the cathode maintained at a high temperature followed by its methanation on a catalyst bed kept at a lower temperature, but both housed inside the same cell. 
cathode itself, the key feature being that the SOEC can be maintained at one single temperature. Contrarily, in mode 4, the catalyst is placed as a separate bed in proximity of the electrode (at some distance from the electrode) in cooler regions of the cell but still within the same cell. So, in this case, the cell features two zones: a high-temperature electrolysis zone, where syngas is produced from coelectrolysis, followed by a catalyst-laden lower temperature zone, where the syngas along with unconverted $\mathrm{CO}_{2}$ undergoes methanation. As is expected, the energy efficiency and cost of methane production will vary for each of these pathways (Luo et al., 2018), and a comparison on the same has been provided in detail in Energy Efficiency of Methane Synthesis via Different Electrochemical Routes.

\section{Challenges and Advancement in the Electrolytic Production of Hydrogen and Syngas in Solid Oxide Electrolytic Cells Integrated With Thermochemical Reactor for Methane Synthesis}

For modes 1 and 2, mentioned above, the materials and design challenges are very similar to the state-of-the-art SOECs, and research has been progressing at different paces consistent with "waves" in hydrogen research and development (R\&D) in general. The advantageous use of SOECs with reduced electrical energy input has been experimentally demonstrated almost 40 years ago by Erdle et al. (1992), followed by Quandt and Streicher (1986) in the 1980s. The key technical issues for SOECs as hydrogen or syngas generators include limited lifetime due to degradation at the electrodes, sealing issues, and high capital costs. Capital cost is a function of several factors, such as production volume and scale of the units, and material supply chain. One might expect a drastic reduction in capital costs with improved cell designs such as microtubular cells (Lei et al., 2017; Chen et al., 2019; Monzón and Laguna-Bercero, 2019), advent of new manufacturing processes such as $3 \mathrm{D}$ printing (Huang et al., 2017; Wei et al., 2019), and advanced automation which can be implied if the technology gains market acceptance. The challenges associated with materials are more fundamental in nature, and the degradation mechanism in SOECs is not yet well understood. It is generally agreed that more $\mathrm{R} \& \mathrm{D}$ is warranted toward designing new electrode materials like double perovskites (Shin et al., 2015; Afroze et al., 2019; Tian et al., 2020) or modification of existing electrodes. When $\mathrm{CO}_{2}$ is added to steam for generation of syngas (mode 2), the issues related to the stability of the electrode become even more challenging.

SOEC cathodes have been under intense investigation over the recent few years as both energy-intensive reactions in SOECs, namely, steam and $\mathrm{CO}_{2}$ splitting (Eqs 4 and 5), occur on this electrode. The state-of-the-art cathode material is a porous cermet comprising YSZ and metallic nickel, as mentioned earlier in Solid Oxide Electrolytic Cell Materials, Designs, and Modes of Operation for Methane Synthesis. Ni provides the electronic conduction pathways and catalytic activity, while the YSZ matrix prevents $\mathrm{Ni}$ particle grain growth and provides ionic conduction pathways leading to an increased triple-phase boundary area (Bandi et al., 1995; Sridhar and Vaniman, 1997; Holtappels et al., 1999; Graves et al., 2011). Although Ni-YSZ is the common choice of fuel electrode due to the high catalytic activity of $\mathrm{Ni}$ in $\mathrm{H}-\mathrm{H}$ (Bourcet and Tantardini, 1994) bond breaking, its pitfalls include accelerated coarsening, agglomeration, and migration away from the electrode-electrolyte interface particularly under electrolysis condition; limited catalytic activity for $\mathrm{CO}_{2}$ splitting; poor stability under variable loading conditions; and reduced mechanical strength in the presence of steam (Hauch et al., 2008; Knibbe et al., 2010b; Iwanschitz et al., 2010; Chen et al., 2013; Khan et al., 2016; Wang Y. et al., 2019). As Ni gets oxidized upon exposure to steam or $\mathrm{CO}_{2}$, an additional supply for partial recycling of generated $\mathrm{H}_{2}$ is required to maintain $\mathrm{Ni}$ in the metallic state. Product gas circulation is not a critical challenge in small lab-scale experiments; however, at the system level, it could pose significant challenges as it adds to the complexity of the plant. If the operation of SOECs is desired without recirculation of the product gas, the operating window must ensure that oxygen partial pressure in the inlet chamber (cathode chamber) always remains below $10^{-14}$ bar. This, in turn, requires SOEC operation with or above particular current densities. In the case of fluctuating electricity supply, such a requirement may lead to curtailing of hydrogen/syngas production if the availability of electricity cannot meet the minimal demand. Alternatively, a complex system control or a backup power can be used, however, at a substantial capital cost penalty. Usually, operation with recirculated gas like hydrogen requires a low steam-tohydrogen ratio in the feed gas with the hydrogen content above $10 \%$, preferably up to $20 \%$ hydrogen with steam. Significant degradation in the performance has been reported by Eguchi et al. (1996) at a higher steam concentration. In a similar observation for $\mathrm{CO}_{2}$ electrolysis, Green et al. (2008) have shown that for a decreasing $\mathrm{CO}_{2} / \mathrm{CO}$ ratio (creating a more reducing environment), polarization resistance offered by an Ni-YSZ cathode first decreases and then increases, which is contrary to the general expectation. This is due to the Nicatalyzed Boudouard reaction leading to enhanced coke deposition that dampens cathode activity. Thus, steam electrolysis demands the cathode to be stable in low $\mathrm{H}_{2}$ partial pressures, but co-electrolysis or $\mathrm{CO}_{2}$ electrolysis poses the additional challenge that cathode should be CO tolerant and coking resistant. Thus, a considerable portion of the current SOEC material development focuses on the development of an alternative cathode which will be stable under a variety of operating conditions.

The development strategies involve either a modification of the Ni-YSZ or a complete substitution with new materials. The modification includes either tailoring of the microstructure or addition of a catalytic phase to the Ni-YSZ, which can improve the catalytic performance of $\mathrm{Ni}$ toward $\mathrm{CO}_{2}$ splitting. Some researchers (Ishihara et al., 2010; Wang et al., 2013; Hong et al., 2015; Kim et al., 2016; Neofytidis et al., 2019; Yu et al., 2020) have tried to evaluate the alloying of $\mathrm{Ni}$ with a second metal as promoter, which alters the work function of $\mathrm{Ni}$, thereby improving its catalytic activity toward steam or $\mathrm{CO}_{2}$ splitting and minimizing issues related to carbon deposition. For example, 
Ishihara et al. (2010) reported that a Ni-Fe bimetallic cathode serves well for steam electrolysis in intermediate temperature SOECs, possibly because Fe effectively increases the rate of $\mathrm{H}_{2}$ formation. Wang et al. (2013) explored a bimetallic Ni-Fe cathode (with YSZ) for electrolysis of $\mathrm{CO}_{2}$ and reported a significant reduction in carbon deposition compared to bare $\mathrm{Ni}$ during a test period of $12 \mathrm{~h}$. Issues such as product recirculation requirement and $\mathrm{Ni}$ migration may still persist, and long-term testing is required.

As for the complete substitution of Ni-YSZ, a wide variety of materials such as perovskites, fluorites, and composites have been studied as prospective cathodes for both hydrogen and syngas generation (Wang Y. et al., 2017; Wang Y. et al., 2019; Jiang, 2019; Pandiyan et al., 2019). Since the key role of Ni in NiYSZ is to provide electronic conduction and catalytic activity toward electroreduction, a pertinent alternative is to seek perovskites that can potentially exhibit these two features. Such ceramics, mainly fluorites and perovskites, belong to the genre of mixed ionic electronic conductors. A plethora of investigations on perovskite electrodes have been reported for SOFCs (Zhu and Deevi, 2003a; Faes et al., 2012; Mahato et al., 2015); however, for SOECs, the number of publications and patents in the area have started increasing only over the past few years.

Yang and Irvine (2008) used strontium and cobalt-stabilized lanthanum manganite $\left(\mathrm{La}_{0.8} \mathrm{Sr}_{0.2} \mathrm{Cr}_{0.5} \mathrm{Mn}_{0.5} \mathrm{O}_{3-\delta}\right.$, commonly referred as LSCM) as the cathode with YSZ as the electrolyte and lanthanum strontium ferrite $\left(\mathrm{La}_{0.7} \mathrm{Sr}_{0.3} \mathrm{FeO}_{3}\right.$, commonly LSF) as the oxygen electrode for steam electrolysis, and achieved startup from a very low hydrogen concentration ( $4 \%$ by volume) without having to overcome high ohmic and polarization resistances as witnessed in $\mathrm{Ni}$-based cathodes prior to the reduction of $\mathrm{NiO}$ to $\mathrm{Ni}$. Another example is doped titanium oxide or titanate cathodes. Titanate perovskites (Yang et al., 2014; Gan et al., 2016; Barnett et al., 2019; Dogu et al., 2019) have been investigated for several years as an alternative to Ni-YSZ. Titanates lack catalytic activity for electrolysis, and the addition of a second catalytic phase becomes necessary. Marina and Pederson (2008) reported a composite ceria-titanate cathode $\left(\mathrm{La}_{0.35} \mathrm{Sr}_{0.65} \mathrm{TiO}_{3}-\mathrm{Ce}_{0.5} \mathrm{La} 0.5 \mathrm{O}_{2}\right)$ which demonstrated substantially lower polarization resistance $\left(0.2-0.28 \Omega \mathrm{cm}^{2}\right)$ than Ni-YSZ $\left(0.4 \Omega \mathrm{cm}^{2}\right)$. Ceria provides additional catalytic activity, and the titanate phase provides electronic conductivity.

Recently, Deka et al. (2019) used Ni- and Co-doped lanthanum strontium ferrite (LSF) cathode for co-electrolysis at $800^{\circ} \mathrm{C}$. Co-electrolysis performed for $110 \mathrm{~h}$ on a $\mathrm{La}_{0.7} \mathrm{Sr}_{0.3} \mathrm{Ni}_{0.1} \mathrm{Co}_{0.1} \mathrm{Fe}_{0.8} \mathrm{O}_{3}$ cathode showed appreciable stability of this composition to coking. Co-doped LSF showed the lowest Faradaic efficiency, whereas Ni-doped LSF gave $~ 100 \%$ Faradaic efficiency (see Table 2 for the performance). Their in situ X-ray near-edge structure studies revealed that during co-electrolysis, Co ions may get oxidized, thereby decreasing the number of oxygen vacancies in the material and lowering its electrochemical activity. Moreover, unlike Ni-doped cathodes, Co-doped ones showed evidence of graphitic carbon formation that could have further reduced the electrochemical performance of the cell.
Doped ceria-based fluorite oxides and related composite cathodes have been gaining popularity over the last few years. It is generally accepted that Ceria $\left(\mathrm{CeO}_{2}\right)$, and in particular aliovalent metal (gadolinium, samarium, or praseodymium)doped ceria such as gadolinia-doped ceria (GDC) or samariadoped ceria, is immune to coking due to the presence of highly mobile surface oxygen species that react with any deposited carbon and suppress coke build-up through gasification (Livermore et al., 2000; Goodenough and Huang, 2007; Cimenti and Hill, 2010; Lee et al., 2016; Elleuch and Halouani, 2020). The presence of such mobile oxygen species is the synergistic effect of oxygen vacancies imparted by the dopant and the in situ reduction of $\mathrm{Ce}^{4+}$ to $\mathrm{Ce}^{3+}$ at $\mathrm{HTs}$ and in a reducing atmosphere. Although not as widely studied for $\mathrm{CO}_{2}$ electrolysis or co-electrolysis, ceria-based electrodes have already proven their merit in SOFCs. Yue and Irvine (2012) compared the cathode performance of LSCM/YSZ and LSCM/GDC composites for $\mathrm{CO}_{2}$ electrolysis and concluded that GDC itself undergoes reduction under applied load, thus offering much lesser polarization resistance and enhanced cathode activity than YSZ. Doped ceria has a conductivity of up to $1 \mathrm{~s} / \mathrm{cm}$ in a reducing atmosphere, and as such, either mixing with an electronically conducting phase is required or an additional current collection layer needs to be coated on the top of the ceria cathode. Recently, LSM and GDC composite was evaluated by Kaur et al. (2018b) as an SOEC cathode for $\mathrm{CO}_{2}$ electrolysis, and it not only exhibited better electrochemical performance but was also found to be significantly more stable. The LSM and related structures provided required electronic conductivity. Kulkarni et al. (2017) observed that at $800^{\circ} \mathrm{C}$, a Pd-doped $\mathrm{La}_{0.8} \mathrm{Sr}_{0.2} \mathrm{Co}_{0.2} \mathrm{Fe}_{0.8} \mathrm{O}_{3-\delta}$ (LSCF) cathode with samaria-doped ceria interlayer and YSZ electrolyte rendered a high Faradaic efficiency of $97 \%$ with minimal overpotential losses (Table 2) for $\mathrm{CO}_{2}$ electrolysis. Ag-GDC composites were evaluated for electrolysis of $\mathrm{CO}_{2}$ (Xie et al., 2015). Ag possesses high electrical conductivity and chemical stability in oxidizing atmospheres above $200^{\circ} \mathrm{C}$, and GDC has high ionic conductivity and good catalytic properties toward $\mathrm{CO}_{2}$ reduction in $\mathrm{CO} / \mathrm{CO}_{2}$ atmospheres, and their composite has shown promising results for $\mathrm{CO}_{2}$ electrolysis. However, any adverse effect of the cell performance due to evaporation of $\mathrm{Ag}$ and possible electromigration needs to be evaluated in long-term tests.

Another important component that has drawn sufficient research interest is the SOEC electrolyte. As of date, YSZ is the most commonly used electrolyte (Graves et al., 2011b; Hansen, $2015 \mathrm{~b})$ due to its high ionic conductivity $(\sim 0.016 \mathrm{~s} / \mathrm{cm})$ along with thermal and chemical stability at the usual operating temperatures of SOECs $\left(800-1,000^{\circ} \mathrm{C}\right)$. However, it fails to exhibit sufficient ionic conductivity in the intermediate temperature range $\left(500-800^{\circ} \mathrm{C}\right)$, which is a major drawback. There are some reports even on the failure of the YSZ electrolyte, which is otherwise thought to be stable under SOFC operating conditions (Graves et al., 2015; Park et al., 2019).

Over the past few decades, substantial efforts have been made to develop an oxygen ion conductor electrolyte which works at 
TABLE 2 | Key cathodes and electrolytes tested for co-electrolysis and $\mathrm{CO}_{2}$ electrolysis at atmospheric pressure.

\begin{tabular}{|c|c|c|c|c|c|}
\hline Group & Cathode|electrolyte|anode & Cathode gas & $T(\mathrm{~K})$ & $\begin{array}{l}\text { Current density in } \mathrm{mA} \mathrm{cm}^{-2} \text { / } \\
\text { (Faradaic efficiency in \%) }\end{array}$ & Notes \\
\hline Faro et al. (2019) & $\begin{array}{l}\mathrm{Ni} / Y S Z|G D C-Y S Z| L S M \\
\mathrm{Gd}_{0.2} \mathrm{Ce}_{0.8} \mathrm{O}_{1.95} \text { (GDC) }\end{array}$ & $\mathrm{H}_{2} \mathrm{O} / \mathrm{CO}_{2}$ & $798-973$ & $350 /(60)$ & - \\
\hline Deka et al. (2019) & $\begin{array}{l}\text { LSNiF|YSZ|LSM-YSZ; LSCoF|YSZ|LSM-YSZ } \\
\text { Ni-doped } \mathrm{La}_{0.7} \mathrm{Sr}_{0.3} \mathrm{FeO}_{3} \text { (LSNiF) } \\
\text { Co-doped } \mathrm{La}_{0.7} \mathrm{Sr}_{0.3} \mathrm{FeO}_{3} \text { (LSCoF) }\end{array}$ & $\mathrm{H}_{2} \mathrm{O} / \mathrm{CO}_{2}$ & 1,073 & $\begin{array}{l}\text { 7/(LSNiF } \sim 100 \\
\quad \text { LSF } \sim 80 \\
\text { LSCoF } \sim 65)\end{array}$ & $\begin{array}{l}\mathrm{H}_{2} \text { production: } \mathrm{LSNiF}>\mathrm{LSF}>\mathrm{LSCoF} \\
\mathrm{CO} \text { production: } \mathrm{LSF}>\mathrm{LSCoF}>\mathrm{LSNiF}\end{array}$ \\
\hline Graves et al.(2011) & NiYYSZ|YSZ|LSM-YSZ & $\mathrm{H}_{2} \mathrm{O} / \mathrm{CO}_{2}$ & $1,023-1,123$ & $250-1,000 /-$ & $\begin{array}{l}\text { Low current density: Cathode degradation }\left(0.005-0.008 \mathrm{mV} \mathrm{h}^{-1}\right) \\
\text { dominated; High current densities: anode degradation } \\
\left(0.1 \mathrm{mV} \mathrm{h}^{-1}\right) \text { dominated }\end{array}$ \\
\hline Pu et al. (2016) & $\begin{array}{l}\text { LSCM|BCZY|LSCM } \\
\mathrm{La}_{0.8} \mathrm{Sr}_{0.2} \mathrm{Cr}_{0.5} \mathbf{M n}_{0.5} \mathbf{O}_{3-\delta} \text { (LSCM) } \\
\mathrm{BaCe}_{0.5} \mathrm{Zr}_{0.3} \mathbf{Y}_{0.2} \mathrm{O}_{3-\delta} \text { (BCZY) }\end{array}$ & $\mathrm{H}_{2} \mathrm{O} / \mathrm{CO}_{2}$ & $723-873$ & 330/(90) & Current density higher than YSZ \\
\hline Kulkarni et al. (2017) & $\begin{array}{l}\text { Pd-LSCF with SDC interlayer |YSZ|LSCF-Ag } \\
\mathrm{La}_{0.8} \mathrm{Sr}_{0.2} \mathrm{Co}_{0.2} \mathrm{Fe}_{0.8} \mathrm{O}_{3-\delta} \text { (LSCF) } \\
\mathrm{Sm}_{0.2} \mathrm{Ce}_{0.8} \mathrm{O}_{1.9} \text { (SDC) }\end{array}$ & $\mathrm{H}_{2} \mathrm{O} / \mathrm{CO}_{2}$ & 1,073 & $360 /(97)$ & Overpotential losses, $200 \mathrm{mV}$ at $350 \mathrm{~mA} \mathrm{~cm}{ }^{-2}$ \\
\hline Wang et al. (2015) & $\begin{array}{l}\mathrm{Ni}-\mathrm{Fe}-\mathrm{LSFM}|\mathrm{LSGM}| \mathrm{BLC} 64 \\
\mathrm{Ba}_{0.6} \mathrm{La}_{0.4} \mathrm{CoO}_{3+\delta}(\mathrm{BLC64}) \\
\mathrm{La}_{0.6} \mathrm{Sr}_{0.4} \mathrm{Fe}_{0.8} \mathrm{Mn}_{0.2} \mathrm{O}_{3} \text { (LSFM) } \\
\mathrm{La}_{0.9} \mathrm{Sr}_{0.1} \mathrm{Ga}_{0.8} \mathrm{Mg}_{0.2} \mathrm{O}_{3} \text { (LSGM) }\end{array}$ & Dry $\mathrm{CO}_{2}$ & $973-1,173$ & 2,320/(96.5) & Cathodes stable for $100 \mathrm{~h}$ at $1.3 \mathrm{~V}$ \\
\hline Zhou et al. (2018) & $\begin{array}{l}\text { LSFV-GDC|YSZ|LSM-YSZ } \\
\text { La }_{0.5} \mathrm{Sr}_{0.5} \mathrm{Fe}_{\mathbf{1 - x}} \mathbf{v}_{\boldsymbol{x}} \mathrm{O}_{3-\delta}(\mathrm{LSFV}) \text { with }(\mathbf{0}<\boldsymbol{x}<\mathbf{0 . 1 5})\end{array}$ & Dry $\mathrm{CO}_{2}$ & 1,073 & $620 /(89.5)$ & $\begin{array}{l}\text { Compared to LSF, LSFV } 0.05 \text { gave } 51.2 \% \text { increase in current } \\
\text { density at } 1.6 \mathrm{~V} \text { and } 30 \% \text { reduction in cell degradation }\end{array}$ \\
\hline Zhang et al. (2016) & $\begin{array}{l}\text { Ce-LSCrF-YSZ|YSZ-GDC|LSCoF-GDC } \\
\mathrm{La}_{0.8} \mathrm{Sr}_{0.2} \mathrm{Co}_{0.2} \mathrm{Fe}_{0.8} \mathrm{O}_{3-\delta}(\mathrm{LSCoF}) \\
\mathrm{La}_{0.65} \mathrm{Sr}_{0.3} \mathrm{Ce}_{0.05} \mathrm{Cr}_{0.5} \mathrm{Fe}_{0.5} \mathrm{O}_{3-\delta} \text { (Ce-LSCrF) }\end{array}$ & Dry $\mathrm{CO}_{2}$ & 1,123 & $1,130 /(87)$ & $\mathrm{Ce}$ doping increased $\mathrm{CO}_{2}$ adsorption and its conversion to $\mathrm{CO}$ \\
\hline Cumming et al. (2016) & $\begin{array}{l}\text { SCT-SDC|YSZ|LSM-YSZ } \\
\mathrm{Sr}_{0.7} \mathrm{Ce}_{0.2} \mathrm{TiO}_{3 \pm \delta} \text { (SCT) }\end{array}$ & $\mathrm{H}_{2} \mathrm{O}-\mathrm{CO}_{2}$ & $923-1,123$ & 263/- & - \\
\hline Ye et al. (2017) & $\begin{array}{l}\mathrm{NiO}-\mathrm{CZI}|\mathrm{CZI}| \mathrm{CZI}-\mathrm{LSM} \\
\mathrm{CaZr}_{0.9} \mathbf{I n}_{0.1} \mathrm{O}_{3-\delta} \text { (CZI) }\end{array}$ & $\mathrm{H}_{2} \mathrm{O}$ & 1,123 & 182/(95) & Cell degraded by $35 \mathrm{~mA} \mathrm{~cm}^{-2}(18 \%)$ over a period of $8 \mathrm{~h}$ \\
\hline
\end{tabular}

Specific electrode/electrolyte compositions have been provided in bold. 
even lower temperatures. For instance, Ishihara et al. (2010) used a lanthanum gallate $\left(\mathrm{LaGaO}_{3}\right)$-based electrolyte for steam electrolysis, which gave optimistic results for intermediate temperatures. Strontium- and magnesium-stabilized lanthanum gallate $\left(\mathrm{La}_{0.8} \mathrm{Sr}_{0.2} \mathrm{Ga}_{0.8} \mathrm{Mg}_{0.2} \mathrm{O}_{3-\delta}\right.$, commonly LSGM) also exhibits good ionic conductivity at intermediate temperatures, but it reacts with the $\mathrm{Ni}$ of fuel electrode, manifested by the formation of a $\mathrm{LaNiO}_{3}$ layer on the electrode surface. Other materials include scandia-stabilized zirconia (ScSZ) (Mat et al., 2019; Pesaran et al., 2019; Pham et al., 2019; Zhigachev et al., 2019; Wang et al., 2020); however, the high cost of scandium (several times higher than that of yttria) is a major issue for practical applications. Another prominent electrolyte family is ceria-based materials (Jaiswal et al., 2019; Raza et al., 2020). The technical issues with these electrolytes for SOEC application are their propensity toward electronic conduction under high applied potential or reducing atmosphere, phase stability in the presence of steam and $\mathrm{CO}_{2}$, and lower mechanical strength than YSZ. Thus, as of now, YSZ continues to be the choice of electrolyte material for commercial SOECs and the most widely used electrolyte for laboratory-scale studies. Table 2 shows observations from some of the key cathodes and electrolytes that have been tested for coelectrolysis and $\mathrm{CO}_{2}$ electrolysis.

The established air electrodes for SOFCs are also materials of choice for SOEC anodes, as previously mentioned in Solid Oxide Electrolytic Cell Materials, Designs, and Modes of Operation for Methane Synthesis. However, rapid degradation due to electrode delamination and changes in electrode-electrolyte interfacial phase assemblage has been reported with LSM-YSZ composites (Chen and Jiang, 2011; Graves et al., 2011; Rashkeev and Glazoff, 2012; Kim et al., 2013; Graves et al., 2015). It is now well-established that a high current density leads to the build-up of high internal oxygen partial pressure at the anode-electrolyte interface, resulting in the entrapment of nano-sized oxygen bubbles that finally causes microstructural damage and electrode delamination (Virkar, 2010; Tietz et al., 2013; Graves et al., 2015; Chatzichristodoulou et al., 2016; Khan et al., 2017). In response to the degradation issues, LSCF-based materials, which are mixed ionic electronic conductors, are being evaluated in SOECs (Guan et al., 2006; Hjalmarsson et al., 2013; Kim and Choi, 2014; Singh et al., 2015). According to one such research conducted by Singh et al. (2015), $\mathrm{CO}_{2}$ electrolysis was carried out at $1,000^{\circ} \mathrm{C}$ using $\mathrm{Ni}-\mathrm{GDC}$ cathode and YSZ electrolyte with two different anodes (LSCF and LSM-YSZ). Under open circuit conditions, LSCF showed much lower anodic polarization resistance $\left(\sim 0.074 \Omega \mathrm{cm}^{2}\right)$ than LSM/YSZ $\left(\sim 0.13 \Omega \mathrm{cm}^{2}\right)$. Also, the LSCF anode remained stable for a constant operation of $9 \mathrm{~h}$ at a current density of $1.2 \mathrm{~A} \mathrm{~cm}^{-2}$. In another work by GE (Guan et al., 2006) using Ni-YSZ as fuel electrode, YSZ as electrolyte, and different perovskites as oxygen electrodes for steam electrolysis at $800^{\circ} \mathrm{C}$ and $1.3 \mathrm{~V}$ for $100 \mathrm{~h}$, the cell degradation rate followed the order: LSCF < LSF < LSM. Although LSCF shows promising results at intermediate current densities, long-term stability testing at high current density is still under investigation. As oxygen evolution is relatively less energy intensive in SOECs, the research emphasis in on engineering the porosity and microstructure of the cathodes (Chatzichristodoulou et al., 2016; Khan et al., 2017) to avoid delamination from the electrolyte. Also, changes in cell operating conditions are being explored. For example, Graves et al. (2015) recently proposed that electrolysis-induced degradation can be reduced by reversibly switching between electrolysis and fuel-cell modes. They reported that for steam electrolysis at a current density of $1 \mathrm{~A} \mathrm{~cm}^{-2}$, the cell voltage increased from 1.33 to $1.73 \mathrm{~V}$ for $420 \mathrm{~h}$ of constant operation, whereas in the reversible mode operation ( $1 \mathrm{~h}$ electrolysis followed by $5 \mathrm{~h}$ fuelcell mode), the cell voltage during the electrolysis part of the cycles remained stable at $1.33 \mathrm{~V}$ over the same span of $420 \mathrm{~h}$.

In addition to electrodes and electrolyte, there are issues associated with cost reduction of interconnects and sealing stability in the presence of steam and gases like $\mathrm{CO}_{2}$ (Zhu and Deevi, 2003b; Lessing, 2007). These are persistent issues with SOFC technology; however, they can be more challenging for SOECs as understandings on the performance and degradation behavior of these components in SOECs are limited. The typical sealing being explored in planar SOEC stacks is edge seal, glass seal, or compressive seal (Lessing, 2007). For the edge sealing, typically a metal frame of ferritic stainless steel is used. Most sealing metal frames have thermal expansion coefficients higher than zirconia $\left(10.5 \mathrm{~K}^{-1} \times 10^{-6} \mathrm{~K}^{-1}\right)$, which led to the development of chromium (Cr)-based alloys with lower thermal expansion coefficients. However, $\mathrm{Cr}$ gets oxidized to $\mathrm{Cr}_{2} \mathrm{O}_{3}$ followed by vaporization and condensation on the electrode and electrolyte surfaces, increasing cell resistance. Thus, low Cr content ironbased steels are presently used for edge sealing and interconnect because of their low cost, easy fabrication methods, and reasonably low thermal expansion coefficient. The development work is also continuing with ceramic materials and coatings like doped lanthanum chromate $\left(\mathrm{LaCrO}_{3}\right)$ which has the potential to attenuate the Cr poisoning effect of metallic interconnects (Cable et al., 2011). Other major challenges include stack design and assemblage, and optimization of manufacturing processes at scale. These challenges are not specific to synthetic methane production but need focused $R \& D$ to meet the performance and life targets for SOECs at a realistic price point. These issues are discussed in detail in SOFC reviews (Balachandran et al., 1989; Lessing, 2007; Shaigan et al., 2010; Ebbesen et al., 2014; Mahato et al., 2015; Mah et al., 2017; Pandiyan et al., 2019; Wang Y. et al., 2019), which apply to SOECs as well.

\section{State of the Art of Purely Electrochemical In Situ Methane Synthesis in Solid Oxide Electrolytic Cells}

A relatively large body of literature work is available on SOEC cathodes for hydrogen or $\mathrm{CO}$, or more recently on syngas production; however, very limited experimentation has been carried out on the in situ synthesis of hydrocarbons where the cathode needs to play an additional role of synthetic catalyst to promote reactions such as methanation. Lately, researchers have 
started investigating in situ methane synthesis in SOECs in a single reactor (Jensen et al., 2003; Bierschenk et al., 2011; Xie et al., 2011; Li et al., 2013; Chen et al., 2014; Chen et al., 2017; Lei et al., 2017; Jensen et al., 2019; Luo et al., 2020) with only $\mathrm{CO}_{2}$ and steam as feedstock (Figure 6) employing either mode 3 or 4 as described in this section.

Xie et al. (2011) were one of the first to perform in situ methanation using a composite of lanthanum-doped strontium titanate $\left(\mathrm{La}_{0.2} \mathrm{Sr}_{0.8} \mathrm{TiO}_{3+\delta}\right.$, commonly LST) and GDC as cathode on YSZ electrolyte and LSM/YSZ composite anode. They used an additional layer of iron catalyst placed in direct contact with the cathode (Figure $6 \mathrm{~A}$ ). At $650^{\circ} \mathrm{C}$, about $2.8 \%$ methane was generated at atmospheric pressure. They suggested that methane yield can be further improved with adequate optimization of reactor design, proper manipulation of pressure, possibly by the usage of backpressure, and catalyst infiltration into cathode instead of placing it atop the cathode.

The effect of temperature, as encountered in in situ methanation, is still ambiguous and has been systematically studied by only a few researchers. According to some studies, in situ methane synthesis should be carried out in dualtemperature zone SOECs (mode 4 described in Basic Working Principle of Solid Oxide Electrolytic Cells and Their Application in Synthetic Methane Production), where the high-temperature region favors endothermic steam $/ \mathrm{CO}_{2}$ co-electrolysis, whereas a catalyst-laden cooler region within the same cell favors exothermic methanation reactions of the in situ-generated syngas (Figure 6B). In one such design, Chen et al. (2014) conducted in situ methanation using an Ni-YSZ cathode, YSZ electrolyte, and LSM-YSZ anode, where the SOEC part was operated at $800^{\circ} \mathrm{C}$ and $1.3 \mathrm{~V}$, and the temperature was gradually decreased to $250^{\circ} \mathrm{C}$ in the Fischer-Tropsch (F-T) regime. Methane yield remained almost constant from 200 to $400^{\circ} \mathrm{C}$ for the F-T section, followed by a sharp decrease with

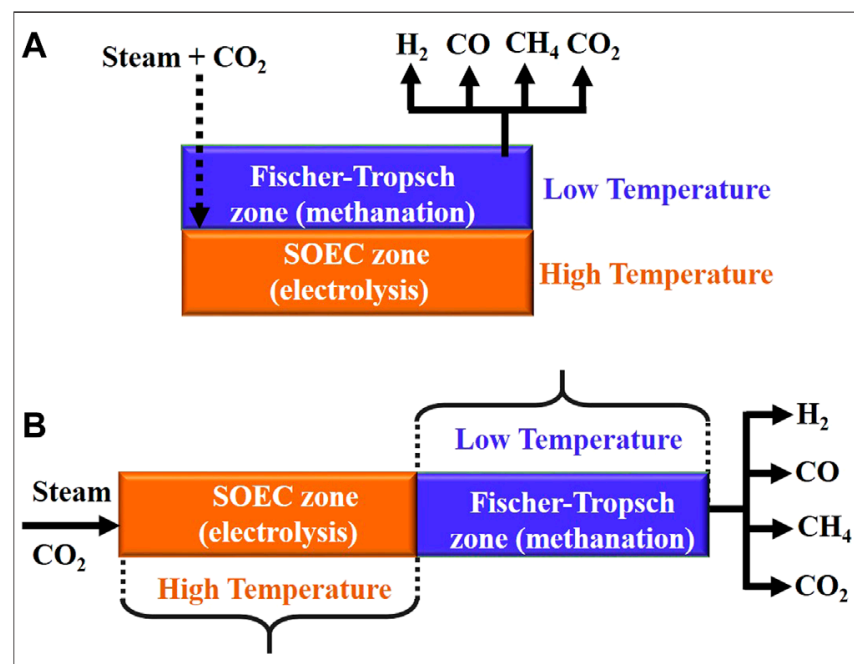

FIGURE 6 | In situ methane synthesis in SOEC in a single temperature zone configuration with catalyst layer above the cathode (A) and dual temperature zone configuration with catalyst beside the cathode (B). further increase in temperature up to $800^{\circ} \mathrm{C}$, as $\mathrm{HT}$ does not favor exothermic $\mathrm{CO}$ methanation reaction (Eq. 2); rather, it promotes methane steam reforming (Eq. 9), which is a competing reaction occurring in the F-T section.

$$
\mathrm{CH}_{4}+\mathrm{H}_{2} \mathrm{O}=\mathrm{CO}+3 \mathrm{H}_{2}\left(\Delta \mathrm{H}_{1,023 \mathrm{~K}}=206 \mathrm{~kJ} \mathrm{~mol}^{-1}\right)
$$

In the SOEC section, as expected, increasing the operating temperature improved the ionic conductivity of the electrolyte, thereby sprucing up the methane output flux. In another study by Lei et al. (2017) using a microtubular SOEC consisting of Ni-YSZ cathode, YSZ electrolyte, and LSM-YSZ anode, the electrolysis zone was operated at $800^{\circ} \mathrm{C}$ and the temperature decreased to $200^{\circ} \mathrm{C}$ in the F-T regime. They obtained a methane yield of $23.1 \%$ with an inlet gas composition of $21.3 \% \mathrm{CO}_{2}, 58.7 \% \mathrm{H}_{2}$, and $20.0 \% \mathrm{H}_{2} \mathrm{O}$ under an electrolysis current density of $0.32 \mathrm{~A} \mathrm{~cm}^{-2}$. Luo et al. (2020) recently proposed a mechanism for in situ methanation in dual-temperature zone SOECs. They said it takes place in three active regions: on the high-temperature zone cathode surface driven by the reaction between inflowing hydrogen and $\mathrm{CO}_{2}$, on the cathode-electrolyte interface driven by rapid hydrogenation of the $\mathrm{CO}$ produced from the electroreduction of $\mathrm{CO}_{2}$, and on the low-temperature zone cathode surface driven by purely heterogeneous catalyst-mediated $\mathrm{CO}_{2} / \mathrm{CO}$ methanation.

Regarding the role of temperature, another school of thought advocates the use of a single temperature $\left(550-650^{\circ} \mathrm{C}\right)$ zone SOEC, where methanation occurs on or in the near vicinity of the cathode itself (mode 3 described in Basic Working Principle of Solid Oxide Electrolytic Cells and Their Application in Synthetic Methane Production). Li et al. (2013) used a button-cell configuration with Ni-YSZ cathode, ScSZ electrolyte, and LSM-ScSZ composite anode at $650^{\circ} \mathrm{C}$ and reported trace amount $(0.29 \%)$ of methane formation. On similar lines, Bierschenk et al. (2011) showed that reducing SOEC operating temperature from 750 to $600^{\circ} \mathrm{C}$ increases methane yield from a merely traceable amount to $14.3 \%$. They further predicted from thermodynamic calculations that increasing the pressure to $10 \mathrm{~atm}$ would further raise the yield to $26.7 \%$. Jensen et al. (2003) showed that the equilibrium methane yield can be raised to over $50 \%$ at $650^{\circ} \mathrm{C}$ and an operating pressure $>15$ bar, and this conclusion also indicates that an intermediate temperature SOEC should be more suitable for methane synthesis. They proposed that co-electrolysis carried out at a pressure as high as $150 \mathrm{~atm}$ and $650^{\circ} \mathrm{C}$ would generate $85 \% \mathrm{CH}_{4}$ and $15 \% \mathrm{H}_{2}$ with minimal $\mathrm{CO}$ and $\mathrm{CO}_{2}$. Jensen et al. (2019) further carried out in situ methanation in an SOFCMAN 301 stack with $30 \mathrm{NiO}$-YSZIYSZIGDCILSCF-GDC planar cells maintained at $700^{\circ} \mathrm{C}$ and 18.7 bar. They reported a methane yield of $18 \%$ at a current density of $0.17 \mathrm{~A} \mathrm{~cm}^{-2}$. In another study, Luo et al. (2020) carried out in situ methanation in a tubular reactor with a Ni-YSZ|Ni-ScSZ bilayer cathode, ScSZ electrolyte, and LSM-ScSZ composite anode under varying conditions of pressure. They showed that under an applied current of $2 \mathrm{~A}$, methane yield of $7 \%$ at $1 \mathrm{~atm}$ increased to $28.7 \%$ at $4 \mathrm{~atm}$. However, with technology related to in situ methanation in SOECs being at a nascent stage, the effect of pressure on methane yield is debated. Contrary to calculations of Jensen and coworkers, Chen et al. (2017) observed that from 1 to 
2.7 bar, the conversion ratio of methane increased and then remained unchanged with further increase in pressure. They explained this phenomenon in terms of the synergistic effect of pressure on methanation reaction rate and current density. On one hand, methanation, being a volume contraction reaction (Eqs 1 and 2), is favored at high pressure, and on the contrary, increase in pressure increases the required voltage for steam and $\mathrm{CO}_{2} \mathrm{CO}-$ electrolysis, thereby slightly reducing the current density that pulls down the syngas production rate.

In addition to temperature and pressure effects, investigations on reaction pathways are also equivocal. Li et al. (2013) proposed that under higher applied voltage, $\mathrm{CO}$ generated in situ dissociates and deposits on the cathode surface as carbon that undergoes hydrogenation to methane. Another interesting possibility is a combinative effect of electric field and catalytic activity on the reaction kinetics by a phenomenon termed as a non-Faradaic electrochemical modification of catalytic activity (NEMCA). In the context of SOECs, it is believed that catalytic activity is enhanced due to the promotion of the work function of catalytic surfaces generated by oxygen ion pumping to/from the electrolyte onto the catalyst surface (Yentekakis and Bebelis, 1992; Yentekakis et al., 1994; Varkaraki et al., 1995; Yentekakis et al., 1995; Frantzis et al., 2000; Cavalca, 2006; Anastasijevic, 2009; Fan, 2012; Theleritis et al., 2012; González-Cobos et al., 2017; López et al., 2019). Unlike structural promoters that improve the dispersion and the chemical stability of the active catalyst phase, electronic promoters directly enhance the catalytic activity of the catalyst itself (Figure 7A).

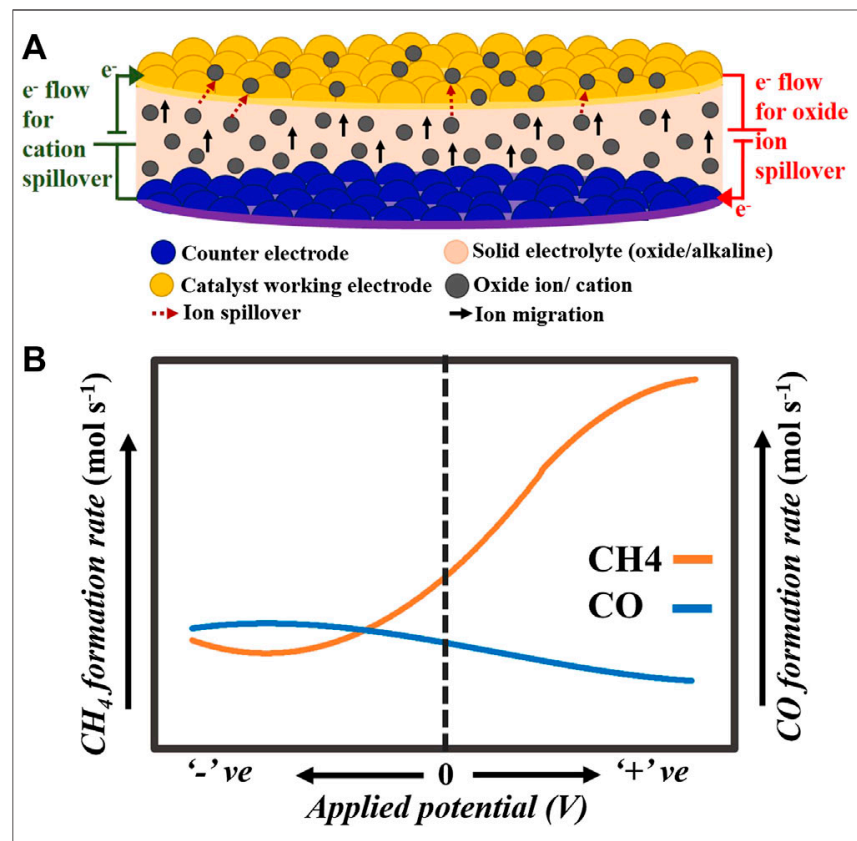

FIGURE 7|A) Schematic of the basic working principle of non-Faradaic electrochemical modification of catalytic activity effect when ions (oxide ions or cations) are pumped to the catalyst working electrode. (B) Pictorial depiction of the trends followed by methane and $\mathrm{CO}$ production rates when $\mathrm{CO}_{2}$ hydrogenation is carried out over a range of negative to positive polarization of the active catalyst surface. Here, both the $y$ axes have the same scale.
For in situ methanation, Anastasijevic (2009) investigated $\mathrm{CO}_{2}$ hydrogenation in light of the NEMCA effect using Ru||YSZ||Au between 200 and $300^{\circ} \mathrm{C}$ under an anodic polarization of $-1.3-1.3 \mathrm{~V}$. Under open-circuit conditions, the rate of $\mathrm{CH}_{4}$ formation was $10^{-4} \mathrm{mmol} \mathrm{s}^{-1}$, which increased to $\sim 2.4 \mathrm{mmol} \mathrm{s}^{-1} \times 10^{-4} \mathrm{mmol} \mathrm{s}^{-1}$ under an applied potential of $1.3 \mathrm{~V}$ and decreased to $\sim 0.6 \mathrm{mmol} \mathrm{s}^{-1} \times 10^{-4} \mathrm{mmol} \mathrm{s}^{-1}$ under $-1.3 \mathrm{~V}$. However, the formation rate and selectivity of $\mathrm{CO}$ exhibited exactly opposite trends, as shown in Figure $7 \mathbf{B}$. There was a monotonic decrease in the rate of $\mathrm{CO}$ formation from $\sim 0.7 \mathrm{mmol} \mathrm{s}^{-1} \times 10^{-4} \mathrm{mmol} \mathrm{s}^{-1}$ under $-1.3 \mathrm{~V}$ to $\sim 0.5 \mathrm{mmol} \mathrm{s}^{-1} \times 10^{-4} \mathrm{mmol} \mathrm{s}^{-1}$ under $1.3 \mathrm{~V}$. The authors concluded that supplying $\mathrm{O}^{2-}$ to the $\mathrm{Ru}$ catalyst surface increases its work function, which, in turn, strengthens the $\mathrm{Ru}-\mathrm{H}$ bond and weakens the $\mathrm{Ru}-\mathrm{CO}$ bond. This suppresses RWGS (Eq. 3) and promotes methanation, thereby increasing methane yield. Contrarily, stripping $\mathrm{O}^{2-}$ away from the $\mathrm{Ru}$ surface decreases its work function, promoting RWGS, and hence CO formation. In another study, Fujiwara et al. (2018) conducted steam $/ \mathrm{CO}_{2}$ co-electrolysis on button cells at $600^{\circ} \mathrm{C}$ using Ni-GDC cathodes, LSCF-GDC anodes, and Hionic substrate (oxide ion conductor) electrolyte. The cathodes were doped with $\mathrm{Pd}$ and $\mathrm{Ru}(0.3 \mathrm{mmol} / \mathrm{g} \mathrm{Ni}-\mathrm{GDC})$. They reported that both $\mathrm{CO}_{2}$ conversion and methane selectivity increased with an increase in applied potential up to $\sim 4 \mathrm{~V}$, which they explained in light of the NEMCA effect. According to them, polarization enriched the cathode surface with electrons, which could have enhanced its catalytic activity toward $\mathrm{CO}_{2}$ conversion via the RWGS reaction (Eq. 3). Nevertheless, there is a dearth of studies that address the NEMCA effect on $\mathrm{CO}_{2}$ methanation, especially for in situ methane synthesis in SOECs.

A summary of the key findings of in situ methanation studies carried out till date is provided in Table 3. The crux of the researches conducted so far on in situ methanation in SOECs is that all of temperature, pressure, operating voltage, inlet gas composition, and most essentially electrode and/or electrocatalyst play pivotal roles in determining the yield of methane. However, to interpret and optimize the operating parameters and determine the type of methanation electrocatalyst that would render the highest yield, a clear perception of the actual reaction mechanism is imperative. Thus, the application of SOECs to produce methane requires further $\mathrm{R} \& \mathrm{D}$ activities focused on a clear perception of the governing reactions, and reaction kinetics thereof, choice of electrode-electrolyte-catalyst combination, and finally, optimization of the operating conditions. Nonetheless, it is worth mentioning that in situ methanation is one of the most efficient ways for synthetic methane production. We have presented a comparison of the energy efficiency of in situ methanation in SOECs with four other routes of methane synthesis in the following section.

\section{ENERGY EFFICIENCY OF METHANE SYNTHESIS VIA DIFFERENT ELECTROCHEMICAL ROUTES}

In this section, we compare the energy requirements and efficiencies of five different routes of methane synthesis 
(Figure 8) which involve the use of PEM, AELs, and SOEC electrolyzers. For SOECs, we considered different modes of operation. In route 1, water electrolysis is carried out in AELs or PEM at near-standard operating conditions $\left(80^{\circ} \mathrm{C}\right.$ and 1 bar) to produce hydrogen, which along with $\mathrm{CO}_{2}$ is fed to a Sabatier reactor (SR) for methane synthesis. In route 2, steam electrolysis is carried out in SOECs to produce hydrogen, which is fed to a SR for methane generation. In route 3 , steam and $\mathrm{CO}_{2}$ are coelectrolyzed in SOECs to generate syngas, which is supplied to a MR for methane synthesis. Route 4 involves in situ synthesis of methane in a two-temperature zone SOEC, where syngas generation from co-electrolysis of steam- $\mathrm{CO}_{2}$ occurs in the high-temperature zone followed by its subsequent methanation in the low-temperature zone. In route 5, dry $\mathrm{CO}_{2}$ electrolysis in SOECs produces $\mathrm{CO}$ that undergoes WGS reaction with steam in a thermochemical reactor to generate a $\mathrm{H}_{2} / \mathrm{CO}_{2}$ mixture that then undergoes methanation in a subsequent $\mathrm{SR}$.

So routes $2-5$ involve SOECs, here assumed to be at $800^{\circ} \mathrm{C}$ and 1 bar, which can be essentially operated in multiple configurations for methane synthesis. It can be used as a source of hydrogen (route 1) or CO (route 5) or syngas (route 3) that undergoes subsequent methanation in a SR or a MR operated at $250^{\circ} \mathrm{C}$ and 25 bar pressure in the presence of state-ofthe-art Ni catalyst. Further, it is possible to use SOECs for onestep methanation (route 4) directly from steam and $\mathrm{CO}_{2}$.

The schematic of the five routes considered here are shown in Figure $\mathbf{8}$ and their corresponding energy efficiencies in Figure 9A. The process energy efficiencies $(\eta)$ are calculated by employing basic enthalpy balance:

Process energy efficiency $(\eta)=\frac{\text { Energy content of product }}{\text { Total energy input }} \times 100$

It is to be noted now that SOECs provide the opportunity to recycle back the exothermic heat of methanation reactions (Eqs 1 and 2); however, the recirculation of heat requires an additional balance of plant which can increase capital costs. So, for each of routes 2,3, and 5, two cases of $\eta$ and energy demand are portrayed (Figures 9A,B): one with heat recycled back from SR or MR to the SOEC being operated at $800^{\circ} \mathrm{C}$ and the other one with no such heat recycle, whereas routes 1 and 4 have only one value of $\eta$; for route 1, there is no scope for heat recycle with AELs/PEM, and for route 4 , exothermic heat is generated in situ within the SOEC itself and is thus available at all times.

Although methane itself is a well-established fuel, it can also be used as a source of hydrogen (at energy penalty) using an established steam methane reforming process in conventional thermochemical reactors or membrane separation catalytic reactors (Kim et al., 2018; Simakov and Román-Leshkov, 2018). When methane was produced via routes 1,2 , and 5 (Eq. 10), the energy efficiency of the process was estimated to be approximately 67,73 , and $80 \%$, respectively, whereas the highest efficiency of $\sim 89 \%$ was calculated for in situ methanation (route 4), as shown in Figure 9A. The round-trip efficiency (RTE) of producing methane from hydrogen and back 

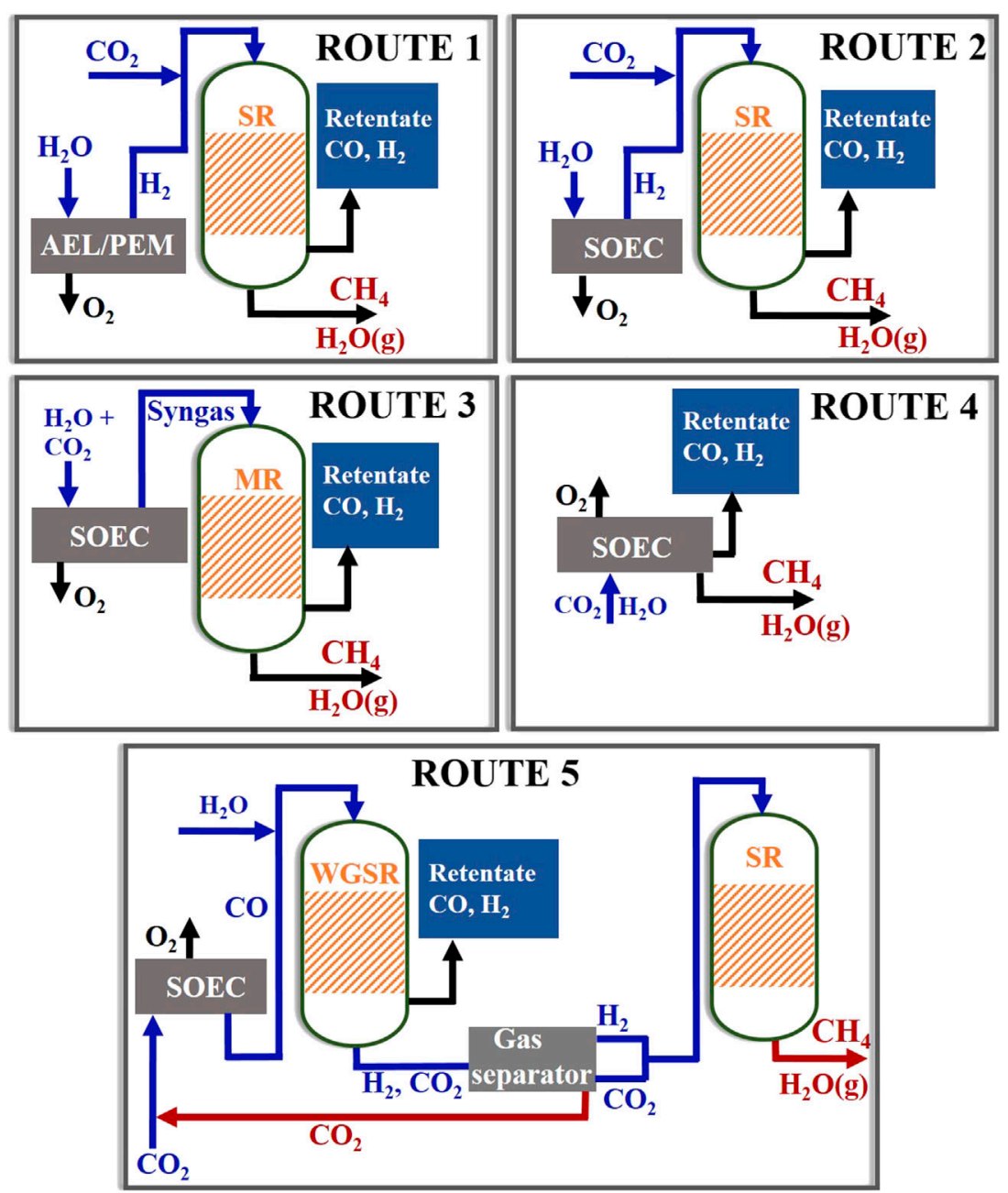

FIGURE 8 | Schematics of five different routes of methane synthesis using electrolysis. Here, SR, MR, WGS, and HE stand for Sabatier reactor, methanation reactor, water-gas shift reactor, and heat exchanger, respectively.

to hydrogen through steam reforming (Figure 9C) was also maximum for route $4(\sim 62 \%)$, followed by route $3(\sim 58 \%)$. Similar RTE $(\sim 65 \%)$ was reported by Jensen et al. (2015) while operating solid oxide cells in reversible mode at nearatmospheric pressure. They modeled the system where methane was synthesized as well as utilized using the same device. However, at high pressure (15 bar), higher efficiencies of up to $70 \%$ were reported by them. In another similar study, Butera et al. (2019) reported that during the reversible operation of solid oxide cells at higher pressures, the RTE can be further increased to $80 \%$ through proper adjustment of the $\mathrm{H} / \mathrm{C}$ ratio of the gases being purged into the cell during both electrolysis and fuel-cell modes.

From preliminary energy balance calculations and considering minimal balance of plant requirements, it can be stated that in situ methanation in SOECs is the most efficient yet relatively cheaper option for methane synthesis as well as hydrogen recovery. For large-scale methane producing plants, the capital costs associated with the integration of separate reactors is substantial. In contrast, in situ methanation in SOECs eliminates the need for separate reactors and auxiliary components, which makes the system relatively compact and reduces plant footprint.

Calculations are based on the following major assumptions:

- During actual cell operation, voltage and current density would dictate the input energy, and thus the energy efficiency of the process. However, what have been reported here are simplistic calculations purely based on thermodynamics, so no current density is involved in this case.

- System losses incurred from the integration of various components such as catalytic recuperator, condenser, humidifier, and gas splitter have not been considered here.

- Heat loss from reactor and pipelines is $5 \%$ of the total heat generated due to exothermic reactions occurring in the SR or MR or WGSR (heat exchanger efficiency 95\%).

- $90 \%$ of each of the gases produced through electrolysis is available for further reactions. 


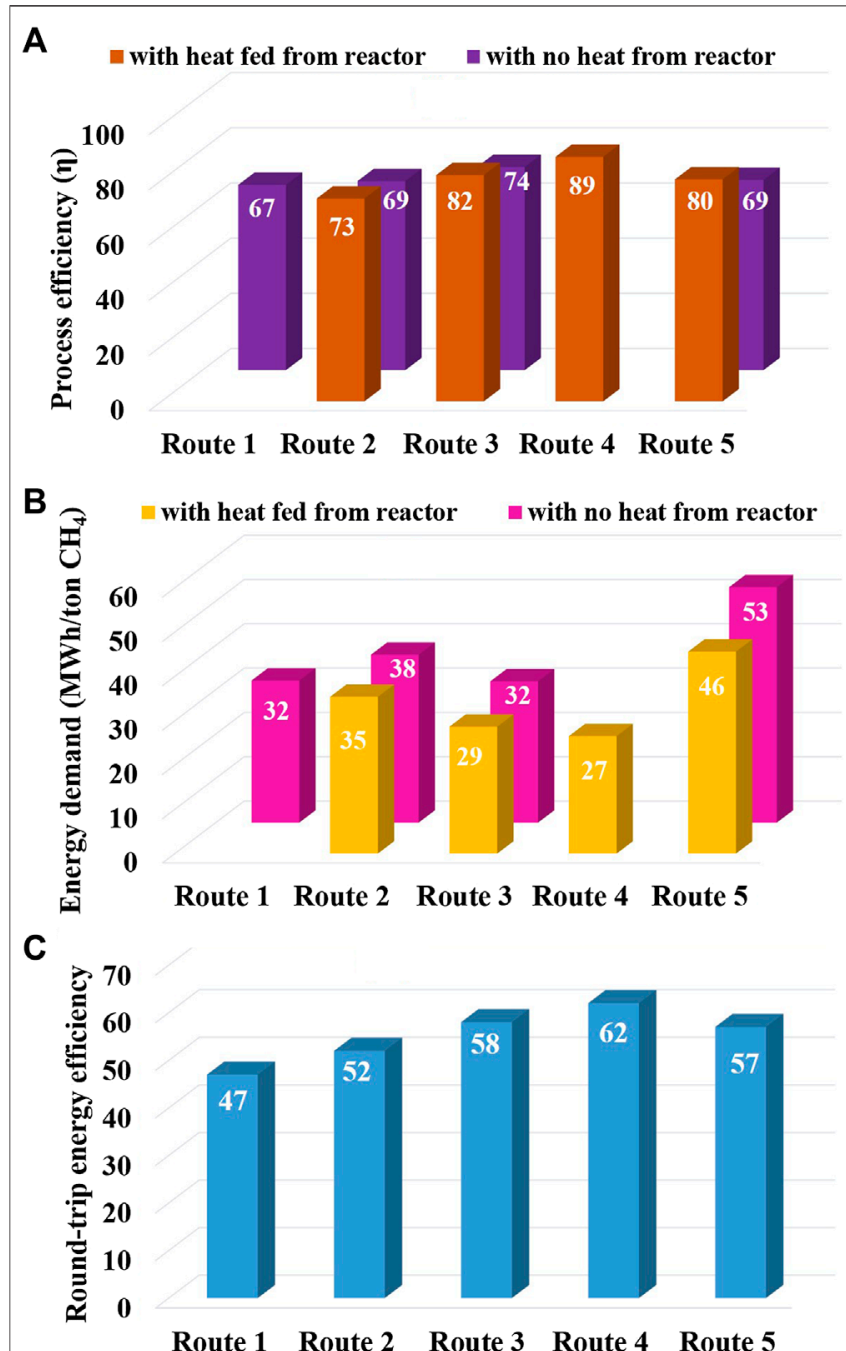

FIGURE 9 | A) Process efficiencies of five different routes of $\mathrm{CH}_{4}$ synthesis. (B) Energy requirements of five different routes of $\mathrm{CH}_{4}$ synthesis. (C) The round-trip efficiency of the five different routes of methane synthesis.

- $100 \%$ of the products generated in the SR, MR, and WGSR are obtained at the reactor outlets.

- In route $5, \mathrm{H}_{2} / \mathrm{CO}_{2}$, produced in the WGSR at the ratio of 1 : 1 , flows to the gas separator from where $\mathrm{H}_{2} / \mathrm{CO}_{2}$ at a ratio of $4: 1$ is sent to the SR and the remaining $\mathrm{CO}_{2}$ is recycled back to the SOEC.

- Electrolyzers are thermally insulated and prevent heat loss to the surrounding.

- For RTE, no losses have been considered for methane compression and transportation, and efficiency of the steam methane reformer for converting methane to hydrogen is $70 \%$.

- RTE calculations are based on the best-case scenario, that is, with heat recycled back from the SR or MR to the SOEC.

- LHV has been used for both methane $(55 \mathrm{KJ} / \mathrm{g})$ and hydrogen $(120 \mathrm{KJ} / \mathrm{g})$.

\section{CONCLUDING REMARKS AND TECHNOLOGY OUTLOOK}

An ever-increasing global energy demand with subsequent development in solar and wind energy systems has made the compelling case for investigations on renewably powered synthetic reactors for the production of hydrogen and hydrogen carriers as a means of energy storage and transport.

Methane, the major component of natural gas, is one of the favorite contenders if the carbon source is waste $\mathrm{CO}_{2}$ produced from industrial or biological processes, or collected from the atmosphere using direct air capture technology, and hydrogen is sourced using renewable sources of energy. Methane itself is a well-established fuel but can potentially be a part of a circular hydrogen economy acting as a source of hydrogen that can be transported over long distances for various applications. The steam methane reforming for hydrogen production is a wellestablished process.

Methane can be synthesized in a SR from $\mathrm{CO}_{2}$ and hydrogen. $\mathrm{CO}_{2}$ can be acquired from carbon capture and sequestration stations and hydrogen from electrolysis of water in AELs or PEM. AEM and PEM are becoming mature technologies for hydrogen production, but both suffer from certain shortcomings, the major one being the high electrical energy demand. In such a pretext, SOECs are being considered eligible candidates for methane synthesis. Although some preliminary research corroborates the huge potential of in situ methane synthesis in SOECs, rigorous investigations on the electrochemical and chemical reaction mechanisms and kinetics, and cell material behavior under the process conditions are required to advance the technology. A balance between SOEC kinetics and a thermodynamically favorable operating window for methane synthesis needs to be achieved, which is a nontrivial challenge.

The areas requiring detailed inspection and development include electrocatalytically active materials selection, cell design, the establishment of overall mechanism and reaction pathways of methanation processes, and optimization of process conditions.

One of the prime constraints of SOEC is the high-temperature operation that tends to reduce the cell materials lifetime and is counterproductive for methanation reaction. This calls for innovation of novel materials as electrolytes that will possess appreciable ionic conductivity at intermediate temperatures $\left(350-600^{\circ} \mathrm{C}\right)$, good chemical stability to endure the redox environment of the SOEC and finally excellent adhesion to the electrodes. Development of electrode materials (cathode) with the desired combination of electrocatalytic properties, mechanical strength, phase stability and electrical conductivity at SOEC operating temperature and environment is another prerequisite.

The choice for cathode materials for one-step methane synthesis (on the same electrode) becomes even more challenging as in addition to the requirements for electrodes to perform co-electrolysis, the activity of methanation also needs to be considered. Materials need to be chosen such that they have low $\mathrm{CO}$ adsorption energies so that the $\mathrm{CO}$ produced in situ can undergo further hydrogenation to yield methane. Oxygen 
evolution being relatively less energy intensive in SOECs, the research emphasis is on engineering the porosity and microstructure of the anodes to avoid delamination from the electrolyte, rather than materials itself.

A second limitation of methane synthesis using SOECs is that the rate-limiting step for electrolysis of $\mathrm{CO}_{2}$ or coelectrolysis of $\mathrm{CO}_{2} / \mathrm{H}_{2} \mathrm{O}$ mixture in SOECs has not yet been unanimously established or determined. For syngas production through co-electrolysis, the role of $\mathrm{CO}_{2}$ electrolysis (Eq. 5) vs. RWGS reaction (Eq. 3) as the major pathway of $\mathrm{CO}$ generation is still debated. As of date, two notions prevail regarding the role of the RWGS reaction in the co-electrolysis of steam and $\mathrm{CO}_{2}$. Some researchers believe that with steam electrolysis being much faster than $\mathrm{CO}_{2}$ electrolysis, only $\mathrm{H}_{2} \mathrm{O}$ splits into hydrogen which then undergoes RWGS reaction with $\mathrm{CO}_{2}$ to produce $\mathrm{CO}$, as RWGS is thermodynamically more favorable. However, others believe that $\mathrm{CO}_{2}$ is electrolyzed to CO. Establishment of the reaction mechanism for in situ methanation poses additional challenges as it follows a complex pathway consisting of primarily four different steps: 1) dissociative adsorption of $\mathrm{CO}_{2}$ on the electrode followed by either its hydrogenation to $\mathrm{CH}_{4}$ (methanation) or CO (RWGS), or even surface reduction to $\mathrm{CO} ; 2$ ) electroreduction of $\mathrm{CO}_{2}$ to $\mathrm{CO}$ at the triple-phase boundary; 3 ) hydrogenation of the $\mathrm{CO}$ produced in situ through steps 1 and 2 to $\mathrm{CH}_{4}$; and 4) electroreduction of the steam generated during in situ methanation to prevent dissociation of methane via steam reforming. The kinetically slowest and hence rate-limiting step will be dictated by the electro-kinetics of the whole process subject to temperature, and such understanding is required to enable material design and optimization of processing conditions to enhance reaction kinetics and methane yield to practical levels.

Other parameters requiring optimization are SOEC operating conditions such as temperature, pressure, current density, voltage, and inlet gas composition. The effect of temperature is still debated; most of the investigations conducted with dualtemperature zone SOECs show that the operation of the SOEC section at higher temperatures improves syngas generation, which would consequently enhance methane yield in the subsequent low-temperature F-T section. However, some other investigations clearly indicate that a single temperature zone SOEC operated at an intermediate temperature ensures improved methane yield. Equally ambiguous is the effect of pressure as discussed in State of the Art of Purely Electrochemical In Situ Methane Synthesis in Solid Oxide Electrolytic Cells. The contribution of the NEMCA effect

\section{REFERENCES}

Acar, C., and Dincer, I. (2019). Review and evaluation of hydrogen production options for better environment. J. Clean. Prod. 218, 835-849. doi:10.1016/j. jclepro.2019.02.046

Afroze, S., Karim, A., Cheok, Q., Eriksson, S., and Azad, A. K. (2019). Latest development of double perovskite electrode materials for solid oxide fuel cells: a review. Front. Energy 13, 770-797. doi:10.1007/s11708-019-0651-x toward the enhanced catalytic activity of electrocatalysts during in situ methane synthesis is also yet to be established.

A sustainable operation meeting the required SOEC kinetics in the temperature range suitable for methanation $\left(300-500^{\circ} \mathrm{C}\right)$ warrants the development of new materials and cell designs functioning effectively in the temperature range. The electrochemical performance targeted for the electrodes and the electrolyte will vary with the design, and this will in turn affect the costs associated with the cell fabrication process. The electrolytesupported cells can be limited in current densities (proportional to hydrogen or syngas production); however, the production costs are usually lower than that of anode-supported cells. On the other hand, the electrode-supported cells can be operated at very high current densities, even exceeding $1 \mathrm{~A} \mathrm{~cm}^{-2}$; however, cost and lifetime are the key challenges. In the opinion of the authors, the capital costs of US $\$ 1,000$ per kilogram (hydrogen) at $1 \mathrm{MW}$ scale can make a compelling commercial case for SOECs, considering competing technologies and hydrogen cost targets.

In a nutshell, exhaustive studies and improvisation, therefore, can make in situ methanation in SOECs an indispensable part of Power-to-Methane technology that is bound to play a key role in the future energy sector.

\section{AUTHOR CONTRIBUTIONS}

SahB, major write up and review; AK, conception, outline, major write up, and review; SG, critical review, content suggestions, and proofreading; SanB, critical review, content suggestions, and proofreading.

\section{FUNDING}

This work received funding from the Australian Renewable Energy Agency (ARENA) as part of ARENA's Research and Development Program-Renewable Hydrogen for Export, and also from CSIRO Hydrogen Energy Systems Future Science Platform, CSIRO Research Office, and a PhD scholarship from Monash University. The funder was not involved in the study design; collection, analysis, and interpretation of data; the writing of the manuscript; or the decision to submit it for publication.

\section{ACKNOWLEDGMENTS}

The authors would also like to thank Daniel Fini for an internal review of the manuscript.

Anastasijevic, N. A. (2009). NEMCA-from discovery to technology. Catal. Today 146, 308-311. doi:10.1016/j.cattod.2009.02.020

Anderson, R. B., Kölbel, H., and Rálek, M. (1984). The Fischer-Tropsch synthesis. New York, NY: Academic Press

Ayers, K. E., Anderson, E. B., Capuano, C., Carter, B., Dalton, L., Hanlon, G., et al. (2010). Research advances towards low cost, high efficiency PEM electrolysis. ECS Trans. 33, 3-15.

Balachandran, U., Dorris, S., Picciolo, J., Poeppel, R., Mcpheeters, C., and Minh, N. (1989). "Material and fabrication challenges in the development of monolithic 
solid oxide fuel cells," in Proceedings of the 24th intersociety energy conversion engineering conference (Piscataway, NJ: IEEE), 1541-1545.

Bandi, A., Specht, M., Weimer, T., and Schaber, K. (1995). $\mathrm{CO}_{2}$ recycling for hydrogen storage and transportation-electrochemical $\mathrm{CO}_{2}$ removal and fixation. Energy Convers. Manag. 36, 899-902. doi:10.1016/0196-8904(95) 00148-7

Barnett, S. A., Zhang, S.-L., Zhu, T., Lu, M. Y., and Mogni, L. V. (2019). “Titanatebased electrodes for solid oxide cells," in 236th ECS meeting, Atlanta, GA, October 13-17, 2019.

Bertuccioli, L., Chan, A., Hart, D., Lehner, F., Madden, B., and Standen, E. (2014). Final report. Study on development of water electrolysis in the EU. The Fuel Cells and Hydrogen Joint Undertaking.

Bhandari, R., Trudewind, C. A., and Zapp, P. (2014). Life cycle assessment of hydrogen production via electrolysis: a review. J. Clean. Prod. 85, 151-163. doi:10.1016/j.jclepro.2013.07.048

Bierschenk, D. M., Wilson, J. R., and Barnett, S. A. (2011). High efficiency electrical energy storage using a methane-oxygen solid oxide cell. Energy Environ. Sci. 4, 944-951. doi:10.1039/c0ee00457j

Bourcet, A., and Tantardini, G. F. (1994). A theoretical study of the adsorption dynamics of hydrogen on $\mathrm{Ni}(111)$ surface. J. Electron. Spectros. Relat. Phenomena 69, 55-64. doi:10.1016/s0368-2048(14)80008-x

Bruce, S., Temminghoff, M., Hayward, J., Schmidt, E., Munnings, C., Palfreyman, D., et al. (2018). National hydrogen roadmap. Australia: CSIRO.

Butera, G., Jensen, S. H., and Clausen, L. R. (2019). A novel system for large-scale storage of electricity as synthetic natural gas using reversible pressurized solid oxide cells. Energy 166, 738-754. doi:10.1016/j.energy.2018.10.079

Buttler, A., and Spliethoff, H. (2018). Current status of water electrolysis for energy storage, grid balancing and sector coupling via power-to-gas and power-toliquids: a review. Renew. Sust. Energ. Rev. 82, 2440-2454. doi:10.1016/j.rser. 2017.09.003

Cable, T. L., Setlock, J. A., Farmer, S. C., and Eckel, A. J. (2011). Regenerative performance of the NASA symmetrical solid oxide fuel cell design. Int. J. Appl. Ceram. Technol. 8, 1-12. doi:10.1111/j.1744-7402.2009.02477.x

Capuano, L. (2018). International energy outlook 2018 (IEO2018). Washington, DC: US Energy Information Administration (EIA), 21.

Carmo, M., Fritz, D. L., Mergel, J., and Stolten, D. (2013). A comprehensive review on PEM water electrolysis. Int. J. Hydrog. Energy 38, 4901-4934. doi:10.1016/j. ijhydene.2013.01.151

Cavalca, C. (2006). Method for low temperature, high activity and selectivity catalytic conversion using electrochemical (NEMCA) cells. Google Patents 20060131179.

Chatzichristodoulou, C., Chen, M., Hendriksen, P. V., Jacobsen, T., and Mogensen, M. B. (2016). Understanding degradation of solid oxide electrolysis cells through modeling of electrochemical potential profiles. Electrochim. Acta 189, 265-282. doi:10.1016/j.electacta.2015.12.067

Chen, B., Xu, H., and Ni, M. (2017). Modelling of SOEC-FT reactor: pressure effects on methanation process. Appl. Energy 185, 814-824. doi:10.1016/j. apenergy.2016.10.095

Chen, K., and Jiang, S. P. (2011). Failure mechanism of (La,Sr) $\mathrm{MnO}_{3}$ oxygen electrodes of solid oxide electrolysis cells. Int. J. Hydrog. Energy 36, 10541-10549. doi:10.1016/j.ijhydene.2011.05.103

Chen, L., Chen, F., and Xia, C. (2014). Direct synthesis of methane from $\mathrm{CO}_{2}-\mathrm{H}_{2} \mathrm{O}$ co-electrolysis in tubular solid oxide electrolysis cells. Energy Environ. Sci. 7, 4018-4022. doi:10.1039/c4ee02786h

Chen, M., Liu, Y.-L., Bentzen, J. J., Zhang, W., Sun, X., Hauch, A., et al. (2013). Microstructural degradation of Ni/YSZ electrodes in solid oxide electrolysis cells under high current. J. Electrochem. Soc. 160, F883-F891. doi:10.1149/2.098308jes

Chen, X., Khor, K., and Chan, S. (2004). Electrochemical behavior of $\mathrm{La}(\mathrm{Sr}) \mathrm{MnO}_{3}$ electrode under cathodic and anodic polarization. Solid State Ion. 167, 379-387. doi:10.1016/j.ssi.2003.08.049

Chen, X., and Shangguan, W. (2013). Hydrogen production from water splitting on CdS-based photocatalysts using solar light. Front. Energy 7, 111-118. doi:10. 1007/s11708-012-0228-4

Chen, Y., Luo, Y., Shi, Y., and Cai, N. (2019). Theoretical Modeling of methane production in pressurized micro-tubular R-SOFC. Energy Procedia 158, 2164-2169. doi:10.1016/j.egypro.2019.01.615

Christian, F., Edith, D., Selly, A., Adityawarman, D., and Indarto, A. (2013). Application of nanotechnologies in the energy sector: a brief and short review. Front. Energy 7, 6-18. doi:10.1007/s11708-012-0219-5
Cimenti, M., and Hill, J. M. (2010). Importance of pyrolysis and catalytic decomposition for the direct utilization of methanol in solid oxide fuel cells. J. Power Sources 195, 54-61. doi:10.1016/j.jpowsour.2009.07.007

Cimon, C., Kadota, P., and Eskicioglu, C. (2020). Effect of biochar and wood ash amendment on biochemical methane production of wastewater sludge from a temperature phase anaerobic digestion process. Bioresour. Technol. 297, 122440. doi:10.1016/j.biortech.2019.122440

Clausen, L. R., Butera, G., and Jensen, S. H. (2019). Integration of anaerobic digestion with thermal gasification and pressurized solid oxide electrolysis cells for high efficiency bio-SNG production. Energy 188, 116018. doi:10.1016/j. energy.2019.116018

Criqui, P., and Kouvaritakis, N. (2000). World energy projections to 2030. Ijgei 14, 116-136. doi:10.1504/ijgei.2000.004385

Cumming, D. J., Thompson, A. R., and Rothman, R. H. (2016). Nickel impregnated cerium-doped strontium titanate fuel electrode: direct carbon dioxide electrolysis and co-electrolysis. J. Electrochem. Soc. 163, F3057. doi:10.1149/ 2.0081611jes

Deka, D. J., Gunduz, S., Fitzgerald, T., Miller, J. T., Co, A. C., and Ozkan, U. S. (2019). Production of syngas with controllable $\mathrm{H}_{2} / \mathrm{CO}$ ratio by high temperature co-electrolysis of $\mathrm{CO}_{2}$ and $\mathrm{H}_{2} \mathrm{O}$ over $\mathrm{Ni}$ and Co-doped lanthanum strontium ferrite perovskite cathodes. Appl. Catal. B Environ. 248, 487-503. doi:10.1016/j.apcatb.2019.02.045

Ding, H., Wu, W., and Ding, D. (2019). Advancement of proton-conducting solid oxide fuel cells and solid oxide electrolysis cells at Idaho national laboratory (INL). ECS Trans. 91, 1029-1034. doi:10.1149/09101.1029ecst

Dogu, D., Gunduz, S., Meyer, K. E., Deka, D. J., Co, A. C., and Ozkan, U. S. (2019). $\mathrm{CO}_{2}$ and $\mathrm{H}_{2} \mathrm{O}$ electrolysis using solid oxide electrolyzer cell (SOEC) with $\mathrm{La}$ and Cl-doped strontium titanate cathode. Catal. Lett. 149, 1743-1752. doi:10.1007/ s10562-019-02786-8

Duan, C., Kee, R., Zhu, H., Sullivan, N., Zhu, L., Bian, L., et al. (2019). Highly efficient reversible protonic ceramic electrochemical cells for power generation and fuel production. Nat Energy 4, 230-240. doi:10.1038/s41560-019-0333-2

Dueñas, D. M. A., Riedel, M., Riegraf, M., Costa, R., and Friedrich, K. A. (2020). High temperature co-electrolysis for power-to-X. Chem. Ing. Tech. 92, 45-52. doi:10.1002/cite.201900119

Ebbesen, S. D., Jensen, S. H., Hauch, A., and Mogensen, M. B. (2014). High temperature electrolysis in alkaline cells, solid proton conducting cells, and solid oxide cells. Chem. Rev. 114, 10697-10734. doi:10.1021/cr5000865

Ebbesen, S. D., and Mogensen, M. (2009). Electrolysis of carbon dioxide in solid oxide electrolysis cells. J. Power Sources 193, 349-358. doi:10.1016/j.jpowsour. 2009.02.093

Eguchi, K., Hatagishi, T., and Arai, H. (1996). Power generation and steam electrolysis characteristics of an electrochemical cell with a zirconia- or ceria-based electrolyte. Solid State Ion. 86-88, 1245-1249. doi:10.1016/01672738(96)00295-0

El Sibai, A., Rihko-Struckmann, L., and Sundmacher, K. (2015). "Synthetic methane from $\mathrm{CO}_{2}$ : dynamic optimization of the Sabatier process for power-to-gas applications," in Computer aided chemical engineering (Amsterdam, Netherlands: Elsevier).

Elleuch, A., and Halouani, K. (2020). "Intermediate-temperature solid oxide fuel cell fueled by biofuels," Intermediate temperature solid oxide fuel cells (Amsterdam, Netherlands: Elsevier).

Erdle, E., Dönitz, W., Schamm, R., and Koch, A. (1992). Reversibility and polarization behaviour of high temperature solid oxide electrochemical cells. Int. J. Hydrogen Energy 17, 817-819. doi:10.1016/0360-3199(92)90026-s

Faes, A., Hessler-Wyser, A., Zryd, A., and Van Herle, J. (2012). A review of RedOx cycling of solid oxide fuel cells anode. Membranes 2, 585-664. doi:10.3390/ membranes 2030585

Fan, Q. (2012). Biofuel production by high temperature non-faradaic electrochemical modification of catalysis. Google Patents 20100258447.

Farla, J. C. M., Hendriks, C. A., and Blok, K. (1995). Carbon dioxide recovery from industrial processes. Clim. Change 29, 439-461. doi:10.1007/bf01092428

Faro, M. L., Zignani, S., Trocino, S., Antonucci, V., and Aricò, A. (2019). New insights on the co-electrolysis of $\mathrm{CO}_{2}$ and $\mathrm{H}_{2} \mathrm{O}$ through a solid oxide electrolyser operating at intermediate temperatures. Electrochim. Acta 296, 458-464.

Foit, S. R., Vinke, I. C., de Haart, L. G. J., and Eichel, R.-A. (2017). Power-to-Syngas: an enabling technology for the transition of the energy system? Angew. Chem. Int. Ed. 56, 5402-5411. doi:10.1002/anie.201607552 
Frantzis, A., Bebelis, S., and Vayenas, C. G. (2000). Electrochemical promotion (NEMCA) of $\mathrm{CH}_{4}$ and $\mathrm{C}_{2} \mathrm{H}_{4}$ oxidation on $\mathrm{Pd} / \mathrm{YSZ}$ and investigation of the origin of NEMCA via AC impedance spectroscopy. Solid State Ion. 36-137, 863-872. doi:10.1016/s0167-2738(00)00528-2

Fujiwara, N., Kikuchi, R., Takagaki, A., and Oyama, S. T. (2018). “Development OF solid oxide electrolysis cell cathodes for direct methanation $\mathrm{IN} \mathrm{CO}_{2} / \mathrm{H}_{2} \mathrm{O} \mathrm{CO}-$ electrolysis," in Grand renewable energy proceedings, Japan, June 17-22, 2018 (Japan: Japan Council for Renewable Energy), 225.

Gan, L., Ye, L., Tao, S., and Xie, K. (2016). Titanate cathodes with enhanced electrical properties achieved via growing surface $\mathrm{Ni}$ particles toward efficient carbon dioxide electrolysis. Phys. Chem. Chem. Phys. 18, 3137-3143. doi:10. 1039/c5cp06742a

Gao, J., Wang, Y., Ping, Y., Hu, D., Xu, G., Gu, F., et al. (2012). A thermodynamic analysis of methanation reactions of carbon oxides for the production of synthetic natural gas. RSC Adv. 2, 2358-2368. doi:10.1039/c2ra00632d

Ghaib, K., and Ben-Fares, F.-Z. (2018). Power-to-Methane: a state-of-the-art review. Renew. Sustain. Energy Rev. 81, 433-446. doi:10.1016/j.rser.2017.08.004

González-Cobos, J., Valverde, J. L., and DE Lucas-Consuegra, A. (2017). Electrochemical vs. chemical promotion in the $\mathrm{H}_{2}$ production catalytic reactions. Int. J. Hydrogen Energy 42, 13712-13723. doi:10.1016/j.ijhydene. 2017.03.085

Goodenough, J. B., and Huang, Y. (2007). Alternative anode materials for solid oxide fuel cells. J. Power Sources 73, 1-10.

Graves, C., Ebbesen, S. D., Jensen, S. H., Simonsen, S. B., and Mogensen, M. B. (2015). Eliminating degradation in solid oxide electrochemical cells by reversible operation. Nat. Mater. 14, 239-244. doi:10.1038/nmat4165

Graves, C., Ebbesen, S. D., and Mogensen, M. (2011). Co-electrolysis of $\mathrm{CO}_{2}$ and $\mathrm{H}_{2} \mathrm{O}$ in solid oxide cells: performance and durability. Solid State Ion. 192, 398-403. doi:10.1016/j.ssi.2010.06.014

Gray, M. L., Champagne, K. J., Fauth, D., Baltrus, J. P., and Pennline, H. (2008). Performance of immobilized tertiary amine solid sorbents for the capture of carbon dioxide. Int. J. Greenh. Gas Con. 2, 3-8. doi:10.1016/s1750-5836(07) 00088-6

Green, R., Liu, C., and Adler, S. (2008). Carbon dioxide reduction on gadoliniadoped ceria cathodes. Solid State Ion. 179, 647-660. doi:10.1016/j.ssi.2008.04.024

Guan, J., Ramamurthi, B., Ruud, J., Hong, J., Riley, P., and Minh, N. (2006). High performance flexible reversible solid oxide fuel cell. GE Global Research Center Final Report for DOE Cooperative Agreement DE-FC36-04GO-14351.

Hansen, J. B. (2015). Solid oxide electrolysis-a key enabling technology for sustainable energy scenarios. Faraday Discuss. 182, 9-48. doi:10.1039/c5fd90071a

Hauch, A., Ebbesen, S. D., Jensen, S. H., and Mogensen, M. (2008). Solid oxide electrolysis cells: microstructure and degradation of the $\mathrm{Ni} / \mathrm{yttria}$-stabilized zirconia electrode. J. Electrochem. Soc. 155, B1184-B1193. doi:10.1149/1.2967331

Hjalmarsson, P., Sun, X., Liu, Y.-L., and Chen, M. (2013). Influence of the oxygen electrode and inter-diffusion barrier on the degradation of solid oxide electrolysis cells. J. Power Sources 223, 349-357. doi:10.1016/j.jpowsour.2012.08.063

Hobson, P. N., Bousfield, S., and Summers, R. (1981). Methane production from agricultural and domestic wastes. Berlin, Germany: Springer.

Holtappels, P., De Haart, L., Stimming, U., Vinke, I. C., and Mogensen, M. (1999). Reaction of $\mathrm{CO} / \mathrm{CO}_{2}$ gas mixtures on Ni-YSZ cermet electrodes. J. Appl. Electrochem. 29, 561-568. doi:10.1023/a:1003446721350

Hong, H. S., Lee, S., and Lee, C. S. (2015). Characterization of (Ni-Cu)/YSZ cermet composites fabricated using high-energy ball-milling: effect of $\mathrm{Cu}$ concentration on the composite performance. Ceram. Int. 41, 6122-6126.

$\mathrm{Hu}, \mathrm{L}$. (2016). Molten carbonate fuel cells for electrolysis. Stockholm, Sweden: KTH Royal Institute of Technology.

Hu, L., Lindbergh, G., and Lagergren, C. (2016). Performance and durability of the molten carbonate electrolysis cell and the reversible molten carbonate fuel cell. J. Phys. Chem. C 120, 13427-13433. doi:10.1021/acs.jpcc.6b04417

Huang, W., Finnerty, C., Sharp, R., Wang, K., and Balili, B. (2017). Highperformance 3D printed microtubular solid oxide fuel cells. Adv. Mater. Technol. 2, 1600258. doi:10.1002/admt.201600258

Ishihara, T., Jirathiwathanakul, N., and Zhong, H. (2010). Intermediate temperature solid oxide electrolysis cell using $\mathrm{LaGaO}_{3}$ based perovskite electrolyte. Energy Environ. Sci. 3, 665-672. doi:10.1039/b915927d

Iwanschitz, B., Sfeir, J., Mai, A., and Schütze, M. (2010). Degradation of SOFC anodes upon redox cycling: a comparison between Ni/YSZ and Ni/CGO. J. Electrochem. Soc. 157, B269-B278. doi:10.1149/1.3271101
Jaiswal, N., Tanwar, K., Suman, R., Kumar, D., Upadhyay, S., Parkash, O., et al. (2019). A brief review on ceria based solid electrolytes for solid oxide fuel cells. J. Alloys Compd. 781, 984-1005. doi:10.1016/j.jallcom.2018.12.015

James, B., Desantis, D., and Saur, G. (2016). Final report: hydrogen production pathways cost analysis (2013-2016). US Department of Energy. Report DOEStrategicAnalysis-6231-1.

Jayakumar, A. (2019). A comprehensive assessment on the durability of gas diffusion electrode materials in PEM fuel cell stack. Front. Energy 173, 1-14.

Jensen, S. H., Graves, C., Mogensen, M., Wendel, C., Braun, R., Hughes, G., et al. (2015). Large-scale electricity storage utilizing reversible solid oxide cells combined with underground storage of $\mathrm{CO}_{2}$ and $\mathrm{CH}_{4}$. Energy Environ. Sci. 8, 2471-2479. doi:10.1039/c5ee01485a

Jensen, S. H., Høgh, J. V. T., Barfod, R., and Mogensen, M. B. (2003). "High temperature electrolysis of steam and carbon dioxide," in Risø international energy conference 2003, Risø, Denmark, May 19-21, 2003, 204-215.

Jensen, S. H., Langnickel, H., Hintzen, N., Chen, M., Sun, X., Hauch, A., et al. (2019). Reversible operation of a pressurized solid oxide cell stack using carbonaceous gases. J. Energy Storage 22, 106-115. doi:10.1016/j.est.2019.02. 003

Jiang, S. P. (2019). Development of lanthanum strontium cobalt ferrite perovskite electrodes of solid oxide fuel cells-a review. Int. J. Hydrog. Energy 44, 7448-7493. doi:10.1016/j.ijhydene.2019.01.212

Junaedi, C., Hawley, K., and Roychoudhury, S. (2014). Sabatier process and apparatus for controlling exothermic reaction. Google Patents US20120029095A1.

Kaur, G., Kulkarni, A. P., and Giddey, S. (2018a). $\mathrm{CO}_{2}$ reduction in a solid oxide electrolysis cell with a ceramic composite cathode: effect of load and thermal cycling. Int. J. Hydrogen Energy 43, 21769-21776. doi:10.1016/j.ijhydene.2018. 10.014

Kaur, G., Kulkarni, A. P., Giddey, S., and Badwal, S. P. S. (2018b). Ceramic composite cathodes for $\mathrm{CO}_{2}$ conversion to $\mathrm{CO}$ in solid oxide electrolysis cells. Appl. Energy 221, 131-138. doi:10.1016/j.apenergy.2018.03.176

Keith, D. W. (2009). Why capture $\mathrm{CO}_{2}$ from the atmosphere? Science 325, 1654-1655. doi:10.1126/science. 1175680

Khan, M. S., Lee, S.-B., Song, R.-H., Lee, J.-W., Lim, T.-H., and Park, S.-J. (2016). Fundamental mechanisms involved in the degradation of nickel-yttria stabilized zirconia (Ni-YSZ) anode during solid oxide fuel cells operation: a review. Ceram. Int. 42, 35-48. doi:10.1016/j.ceramint.2015.09.006

Khan, M. S., Xu, X., Zhao, J., Knibbe, R., and Zhu, Z. (2017). A porous yttriastabilized zirconia layer to eliminate the delamination of air electrode in solid oxide electrolysis cells. J. Power Sources 359, 104-110. doi:10.1016/j.jpowsour. 2017.05.049

Kim, C.-H., Han, J.-Y., Lim, H., Lee, K.-Y., and Ryi, S.-K. (2018). Hydrogen production by steam methane reforming in membrane reactor equipped with $\mathrm{Pd}$ membrane deposited on $\mathrm{NiO} / \mathrm{YSZ} / \mathrm{NiO}$ multilayer-treated porous stainless steel. J. Membr. Sci. 563, 75-82. doi:10.1016/j.memsci.2018.05.037

Kim, J., Ji, H.-I., Dasari, H. P., Shin, D., Song, H., Lee, J.-H., et al. (2013). Degradation mechanism of electrolyte and air electrode in solid oxide electrolysis cells operating at high polarization. Int. J. Hydrogen Energy 38, 1225-1235. doi:10.1016/j.ijhydene.2012.10.113

Kim, J., Kim, G.-D., Moon, J.-W., Park, Y.-I., Lee, W.-H., Kobayashi, K., et al. (2001). Characterization of LSMâ"YSZ composite electrode by ac impedance spectroscopy. Solid State Ion. 143, 379-389. doi:10.1016/s0167-2738(01)00877-3

Kim, S. J., and Choi, G. M. (2014). Stability of LSCF electrode with GDC interlayer in YSZ-based solid oxide electrolysis cell. Solid State Ion. 262, 303-306. doi:10. 1016/j.ssi.2014.01.001

Kim, S.-W., Park, M., Kim, H., Yoon, K. J., Son, J.-W., Lee, J.-H., et al. (2016). Catalytic effect of $\mathrm{Pd}-\mathrm{Ni}$ bimetallic catalysts on high-temperature coelectrolysis of steam $/ \mathrm{CO}_{2}$ Mixtures. J. Electrochem. Soc. 163, F3171. doi:10. $1149 / 2.0251611$ jes

Kim, Y., and Worrell, E. (2002). International comparison of $\mathrm{CO}_{2}$ emission trends in the iron and steel industry. Energy Policy 30, 827-838. doi:10.1016/s03014215(01)00130-6

Knibbe, R., Traulsen, M. L., Hauch, A., Ebbesen, S. D., and Mogensen, M. (2010). Solid oxide electrolysis cells: degradation at high current densities. J. Electrochem. Soc. 157, B1209-B1217. doi:10.1149/1.3447752

Kofler, R., Butera, G., Jensen, S. H., and Clausen, L. R. (2019). "Novel hybrid electricity storage system producing synthetic natural gas by integrating 
biomass gasification with pressurized solid oxide cells," in 32nd international conference on efficiency, cost, optimization, simulation and environmental impact of energy systems, Wrocław, Poland, June 23-28, 2019.

Kondratenko, E. V., Mul, G., Baltrusaitis, J., Larrazábal, G. O., and Pérez-Ramírez, J. (2013). Status and perspectives of $\mathrm{CO}_{2}$ conversion into fuels and chemicals by catalytic, photocatalytic and electrocatalytic processes. Energy Environ. Sci. 6, 3112-3135. doi:10.1039/c3ee41272e

Kulkarni, A. P., Giddey, S., and Badwal, S. P. S. (2017). Efficient conversion of $\mathrm{CO}_{2}$ in solid oxide electrolytic cells with Pd doped perovskite cathode on ceria nanofilm interlayer. J. $\mathrm{CO}_{2}$ Util. 17, 180-187. doi:10.1016/j.jcou.2016.11.014

Lackner, K. S. (2003). Climate change: a guide to $\mathrm{CO}_{2}$ sequestration. Science 300, 1677-1678. doi:10.1126/science.1079033

Laguna-Bercero, M. A. (2012). Recent advances in high temperature electrolysis using solid oxide fuel cells: a review. J. Power Sources 203, 4-16. doi:10.1016/j. jpowsour.2011.12.019

Laguna-Bercero, M. A., Kilner, J. A., and Skinner, S. J. (2011). Development of oxygen electrodes for reversible solid oxide fuel cells with scandia stabilized zirconia electrolytes. Solid State Ion. 192, 501-504. doi:10.1016/j.ssi.2010.01.003

Leah, R. T., Bone, A., Hammer, E., Selcuk, A., Rahman, M., Clare, A., et al. (2017). Development progress on the Ceres power steel cell technology platform: further progress towards commercialization. ECS Trans. 78, 87. doi:10.1149/ 07801.0087ecst

Lee, J. G., Jeon, O. S., Hwang, H. J., Jang, J., Lee, Y., Hyun, S. H., et al. (2016). Durable and high-performance direct-methane fuel cells with coke-tolerant ceria-coated Ni catalysts at reduced temperatures. Electrochim. Acta 191, 677-686. doi:10.1016/j.electacta.2016.01.091

Lei, L., Liu, T., Fang, S., Lemmon, J. P., and Chen, F. (2017). The co-electrolysis of $\mathrm{CO}_{2}-\mathrm{H}_{2} \mathrm{O}$ to methane via a novel micro-tubular electrochemical reactor. J. Mater. Chem. 5, 2904-2910. doi:10.1039/c6ta10252b

Lessing, P. A. (2007). A review of sealing technologies applicable to solid oxide electrolysis cells. J. Mater. Sci. 42, 3465-3476. doi:10.1007/s10853-006-0409-9

Li, W., Wang, H., Shi, Y., and Cai, N. (2013). Performance and methane production characteristics of $\mathrm{H}_{2} \mathrm{O}-\mathrm{CO}_{2}$ co-electrolysis in solid oxide electrolysis cells. Int. J. Hydrog. Energy 38, 11104-11109. doi:10.1016/j.ijhydene.2013.01.008

Livermore, S. J. A., Cotton, J. W., and Ormerod, R. M. (2000). Fuel reforming and electrical performance studies in intermediate temperature ceria-gadolinia-based SOFCs. J. Power Sources 86, 411-416. doi:10.1016/s0378-7753(99)00493-0

López, E. R., Dorado, F., and de Lucas-Consuegra, A. (2019). Electrochemical promotion for hydrogen production via ethanol steam reforming reaction. Appl. Catal. B Environ. 243, 355-364. doi:10.1016/j.apcatb.2018.10.062

Luo, Y., Shi, Y., Chen, Y., Li, W., Jiang, L., and Cai, N. (2020). Pressurized tubular solid oxide $\mathrm{H}_{2} \mathrm{O} / \mathrm{CO}_{2}$ co-electrolysis cell for direct power-to-methane. AIChE J. 66, e16896.

Luo, Y., Wu, X.-Y., Shi, Y., Ghoniem, A. F., and Cai, N. (2018). Exergy analysis of an integrated solid oxide electrolysis cell-methanation reactor for renewable energy storage. Appl. Energy 215, 371-383. doi:10.1016/j.apenergy.2018.02.022

Mah, J. C. W., Muchtar, A., Somalu, M. R., and Ghazali, M. J. (2017). Metallic interconnects for solid oxide fuel cell: a review on protective coating and deposition techniques. Int. J. Hydrogen Energy 42, 9219-9229. doi:10.1016/j. ijhydene.2016.03.195

Mahato, N., Banerjee, A., Gupta, A., Omar, S., and Balani, K. (2015). Progress in material selection for solid oxide fuel cell technology: a review. Prog. Mater. Sci. 72, 141-337. doi:10.1016/j.pmatsci.2015.01.001

Makridis, S. (2017). Hydrogen storage and compression. arXiv:1702.06015 [Preprint]. Available at: https://arxiv.org/abs/1702.06015 (Accessed July 7, 2020).

Marina, O. A., and Pederson, L. R. (2008). Composite solid oxide fuel cell anode based on ceria and strontium titanate. Google Patents US7468218B2.

Mat, Z. A., Nadaraja, S. K., Zakaria, Z., Hassan, S. H. A., Kar, Y. B., Tan, C. Y., et al. (2019). Fabrication and characterization of YSZ/ScSZ bilayer electrolyte for intermediate temperature-solid oxide fuel cell (IT-SOFC) application. Int. J. Integr. Eng. 1, 201-208.

Mazloomi, S. K., and Sulaiman, N. (2012). Influencing factors of water electrolysis electrical efficiency. Renew. Sustain. Energy Rev. 16, 4257-4263. doi:10.1016/j. rser.2012.03.052

Mcdonagh, S., O'Shea, R., Wall, D. M., Deane, J. P., and Murphy, J. D. (2018). Modelling of a power-to-gas system to predict the levelised cost of energy of an advanced renewable gaseous transport fuel. Appl. Energy 215, 444-456. doi:10. 1016/j.apenergy.2018.02.019
Mebrahtu, C., Krebs, F., Abate, S., Perathoner, S., Centi, G., and Palkovits, R. (2019). " $\mathrm{CO}_{2}$ methanation: principles and challenges," in Studies in surface science and catalysis (Amsterdam, Netherlands: Elsevier).

Méndez, C. I., and Ancheyta, J. (2020). Modeling and control of a Fischer-Tropsch synthesis fixed-bed reactor with a novel mechanistic kinetic approach. Chem. Eng. J. 390, 124489. doi:10.1016/j.cej.2020.124489

Mills, G. A., and Steffgen, F. W. (1974). Catalytic methanation. Catal. Rev. 8, 159-210. doi:10.1080/01614947408071860

Monzón, H., and Laguna-Bercero, M. A. (2019). $\mathrm{CO}_{2}$ and steam electrolysis using a microtubular solid oxide cell. J. Phys. Energy 2, 014005. doi:10.1088/2515-7655/ ab4250

Murakami, K., Matsui, T., Kikuchi, R., Muroyama, H., and Eguchi, K. (2010). Activation of LSM electrode related to the potential oscillation under cathodic polarization. J. Electrochem. Soc. 157, B880-B884. doi:10.1149/1.3374407

Murugesan, P., Narayanan, S., and Manickam, M. (2020). "Photocatalytic conversion of carbon dioxide into hydrocarbons," in Conversion of carbon dioxide into hydrocarbons (Berlin, Germany: Springer).

Neofytidis, C., Ioannidou, E., Sygellou, L., Kollia, M., and Niakolas, D. K. (2019). Affecting the $\mathrm{H}_{2} \mathrm{O}$ electrolysis process in SOECs through modification of $\mathrm{NiO} /$ GDC: experimental case of Au-Mo-Ni synergy. J. Catal. 373, 260-275. doi:10. 1016/j.jcat.2019.04.002

Newell, R., Iler, S., and Raimi, D. (2018). Global energy outlook comparison methods: 2019 update. Resources for the Future, April, 26.

Nikolaidis, P., and Poullikkas, A. (2017). A comparative overview of hydrogen production processes. Renew. Sustain. Energy Rev. 67, 597-611. doi:10.1016/j. rser.2016.09.044

Paidar, M., Fateev, V., and Bouzek, K. (2016). Membrane electrolysis-history, current status and perspective. Electrochim. Acta 209, 737-756. doi:10.1016/j. electacta.2016.05.209

Pandiyan, A., Uthayakumar, A., Subrayan, R., Cha, S. W., and Krishna Moorthy, S. B. (2019). Review of solid oxide electrolysis cells: a clean energy strategy for hydrogen generation. Nanomater. Energy 8, 2-22. doi:10.1680/jnaen.18.00009

Park, B.-K., Zhang, Q., Liu, Q., Voorhees, P. W., and Barnett, S. A. (2019). Understanding of solid oxide electrolysis cell degradation: the role of the electrode overpotential. Meeting abstracts. Pennington, NJ: The Electrochemical Society, 1890.

Pesaran, A., Jaiswal, A., and Wachsman, E. D. (2019). "Bilayer electrolytes for low temperature and intermediate temperature solid oxide fuel cells: a review," in Energy storage and conversion materials (Croydon, UK: Royal Society of Chemistry), 1-41.

Peterson, D., and Miller, E. (2016). Hydrogen production cost from solid oxide electrolysis. Hinton, IA: United States Department of Energy.

Pham, T. T., Tu, H. P., Dao, T. D., To, T. D., Doan, D. C. T., and Dang, M. C. (2019). Fabrication of an anode functional layer for an electrolyte-supported solid oxide fuel cell using electrohydrodynamic jet printing. Nanotechnology 10 , 015004. doi:10.1088/2043-6254/aafdab

Prabhukhot Prachi, R., Wagh Mahesh, M., and Gangal Aneesh, C. (2016). A review on solid state hydrogen storage material. Adv. Energy Power 4, 11.

$\mathrm{Pu}, \mathrm{T}$., Tan, W., Shi, H., Na, Y., Lu, J., and Zhu, B. (2016). Steam/CO electrolysis in symmetric solid oxide electrolysis cell with barium cerate-carbonate composite electrolyte. Electrochim. Acta 190, 193-198. doi:10.1016/j.electacta.2015.12.220

Quandt, K., and Streicher, R. (1986). Concept and design of a $3.5 \mathrm{MW}$ pilot plant for high temperature electrolysis of water vapor. Int. J. Hydrogen Energy 11, 309-315. doi:10.1016/0360-3199(86)90149-7

Rashid, M. M., AL Mesfer, M. K., Naseem, H., and Danish, M. (2015). Hydrogen production by water electrolysis: a review of alkaline water electrolysis, PEM water electrolysis and high temperature water electrolysis. Int. J. Eng. Adv. Technol. 4, 2249-8958.

Rashkeev, S. N., and Glazoff, M. V. (2012). Atomic-scale mechanisms of oxygen electrode delamination in solid oxide electrolyzer cells. Int. J. Hydrogen Energy 37, 1280-1291. doi:10.1016/j.ijhydene.2011.09.117

Raza, R., Zhu, B., Rafique, A., Naqvi, M. R., and Lund, P. (2020) Functional ceriabased nanocomposites for advanced low-temperature $\left(300-600^{\circ} \mathrm{C}\right)$ solid oxide fuel cell: a comprehensive review. Mater. Today Energy 15, 100373. doi:10.1016/ j.mtener.2019.100373

Rego de Vasconcelos, B., and Lavoie, J.-M. (2019). Recent advances in power-to-X technology for the production of fuels and chemicals. Front. Chem. 7, 392.

Renewables (2018). Analysis and forecast to 2023, France 2018, IEA. 
Rönsch, S., Schneider, J., Matthischke, S., Schlüter, M., Götz, M., Lefebvre, J., et al. (2016). Review on methanation-From fundamentals to current projects. Fuel 166, 276-296. doi:10.1016/j.fuel.2015.10.111

Sahebdelfar, S., and Takht Ravanchi, M. (2015). Carbon dioxide utilization for methane production: a thermodynamic analysis. J. Petrol. Sci. Eng. 134, 14-22. doi:10.1016/j.petrol.2015.07.015

Santos, D. M. F., Sequeira, C. A. C., and Figueiredo, J. L. (2013). Hydrogen production by alkaline water electrolysis. Quím. Nova 36, 1176-1193. doi:10. 1590/s0100-40422013000800017

Saracoglu, B. O., Ohunakin, O. S., Adelekan, D. S., Gill, J., Atiba, O. E., Okokpujie, I. P., et al. (2018). A framework for selecting the location of very large photovoltaic solar power plants on a global/supergrid. Energy Rep. 4, 586-602. doi:10.1590/s0100-40422013000800017.

Schmidt, O., Gambhir, A., Staffell, I., Hawkes, A., Nelson, J., and Few, S. (2017). Future cost and performance of water electrolysis: an expert elicitation study. Int. J. Hydrog. Energy 42, 30470-30492. doi:10.1016/j.ijhydene.2017.10.045

Schulz, H.. (1999). Short history and present trends of Fischer-Tropsch synthesis. Appl. Catal. Gen. 186, 3-12. doi:10.1016/s0926-860x(99)00160-x

Shaigan, N., Qu, W., Ivey, D. G., and Chen, W. (2010). A review of recent progress in coatings, surface modifications and alloy developments for solid oxide fuel cell ferritic stainless steel interconnects. J. Power Sources 195, 1529-1542. doi:10.1016/j.jpowsour.2009.09.069

Shi, X., Luo, Y., Li, W., Ni, M., and Cai, N. (2015). "Energy efficiencies in ASEAN region," in Handbook of Clean Energy Systems (Hoboken, NJ: Wiley), 1-19. doi:10.1002/9781118991978.hces146

Shin, T. H., Myung, J.-H., Verbraeken, M., Kim, G., and Irvine, J. T. S. (2015). Oxygen deficient layered double perovskite as an active cathode for $\mathrm{CO}_{2}$ electrolysis using a solid oxide conductor. Faraday Discuss. 182, 227-239. doi:10.1039/c5fd00025d

Simakov, D. S. A., and Román-Leshkov, Y. (2018). Highly efficient methane reforming over a low-loading $\mathrm{Ru} / \gamma-\mathrm{Al}_{2} \mathrm{O}_{3}$ catalyst in a $\mathrm{Pd}-\mathrm{Ag}$ membrane reactor. AIChE J. 64, 3101-3108. doi:10.1002/aic.16094

Singh, V., Muroyama, H., Matsui, T., Hashigami, S., Inagaki, T., and Eguchi, K. (2015). Feasibility of alternative electrode materials for high temperature $\mathrm{CO}_{2}$ reduction on solid oxide electrolysis cell. J. Power Sources 293, 642-648. doi:10. 1016/j.jpowsour.2015.05.088

Smart, W., and Weissbart, J. (1967). Study of electrolytic dissociation of CO2-H2O using a solid oxide electrolyte, NASA CR-680.

Sridhar, K., and Vaniman, B. T. (1997). Oxygen production on Mars using solid oxide electrolysis. Solid State Ion. 93, 321-328. doi:10.1016/s0167-2738(96) 00513-9

Tanaka, N. J. (2010). World energy outlook 2010, Beijing, China, November 17, 2010 (Paris, France: International Energy Agency).

Taylor, M., Tam, C., and Gielen, D. (2006). "Energy efficiency and $\mathrm{CO}_{2}$ emissions from the global cement industry," in IEA-WBCSD workshop, Paris, September 4-5, 2006 (Paris, France: International Energy Agency), 61-67.

Theleritis, D., Souentie, S., Siokou, A., Katsaounis, A., and Vayenas, C. G. (2012). Hydrogenation of $\mathrm{CO}_{2}$ over $\mathrm{Ru} / \mathrm{YSZ}$ electropromoted catalysts. ACS Catal. 2, 770-780. doi:10.1021/cs300072a.

Tian, Y., Liu, Y., Wang, W., Jia, L., Pu, J., Chi, B., et al. (2020). High performance and stability of double perovskite-type oxide $\mathrm{NdBa}_{0.5} \mathrm{Ca}_{0.5} \mathrm{Co}_{1.5} \mathrm{Fe}_{0.5} \mathrm{O}_{5+}$ as an oxygen electrode for reversible solid oxide electrochemical cell. J. Energy Chem. 43, 108-115. doi:10.1016/j.jechem.2019.08.010

Tietz, F., Sebold, D., Brisse, A., and Schefold, J. (2013). Degradation phenomena in a solid oxide electrolysis cell after 9,000 h of operation. J. Power Sources 223, 129-135. doi:10.1016/j.jpowsour.2012.09.061

Tucker, M. C. (2010). Progress in metal-supported solid oxide fuel cells: a review. J. Power Sources 195, 4570-4582. doi:10.1016/j.jpowsour.2010.02.035

Ulleberg, O. (2003). Modeling of advanced alkaline electrolyzers: a system simulation approach. Int. J. Hydrogen Energy 28, 21-33. doi:10.1016/s03603199(02)00033-2

Ursua, A., Gandia, L. M., and Sanchis, P. (2012). Hydrogen production from water electrolysis: current status and future trends. Proc. IEEE 100, 410-426. doi:10. 1109/jproc.2011.2156750

Vøllestad, E., Strandbakke, R., Tarach, M., Catalán-Martínez, D., Fontaine, M.-L., Beeaff, D., et al. (2019). Mixed proton and electron conducting double perovskite anodes for stable and efficient tubular proton ceramic electrolysers. Nat. Mater. 18, 752-759. doi:10.1038/s41563-019-0388-2
Van Der Laan, G. P., and Beenackers, A. (1999). Kinetics and selectivity of the Fischer-Tropsch synthesis: a literature review. Catal. Rev. 41, 255-318. doi:10. 1081/cr-100101170

Van Straelen, J., Geuzebroek, F., Goodchild, N., Protopapas, G., and Mahony, L. (2010). $\mathrm{CO}_{2}$ capture for refineries, a practical approach. Int. J. Greenh. Gas Con. 4, 316-320. doi:10.1016/j.ijggc.2009.09.022

Vandenborre, H., Leysen, R., and Baetsle, L. (1980). Alkaline inorganic-membraneelectrolyte (IME) water electrolysis. Int. J. Hydrog. Energy 5, 165-171. doi:10. 1016/0360-3199(80)90093-2

Varkaraki, E., Nicole, J., Plattner, E., Comninellis, C., and Vayenas, C. (1995). Electrochemical Promotion of $\mathrm{IrO}_{2}$ catalyst for the gas phase combustion of ethylene. J. Appl. Electrochem. 5, 978-981. doi:10.1007/bf00241594

Verhelst, S., and Wallner, T. (2009). Hydrogen-fueled internal combustion engines. Prog. Energy Combust. Sci. 35, 490-527. doi:10.1016/j.pecs.2009.08.001

Vermeiren, P., Adriansens, W., Moreels, J., and Leysen, R. (1998). Evaluation of the Zirfon $^{\varpi}$ separator for use in alkaline water electrolysis and $\mathrm{Ni}-\mathrm{H}_{2}$ batteries. Int. J. Hydrog. Energy. 23, 321-324. doi:10.1016/s0360-3199(97)00069-4

Virkar, A. V. (2010). Mechanism of oxygen electrode delamination in solid oxide electrolyzer cells. Int. J. Hydrog. Energy 35, 9527-9543. doi:10.1016/j.ijhydene. 2010.06.058

Wang, K., Fang, Z., Huang, X., Feng, W., Wang, Y., Wang, B., et al. (2017). Enhanced selectivity of methane production for photocatalytic reduction by the piezoelectric effect. Chem. Commun. 53, 9765-9768. doi:10.1039/c7cc05112c

Wang, L., Pérez-Fortes, M., Madi, H., Diethelm, S., Herle, J. V., and Maréchal, F. (2018). Optimal design of solid-oxide electrolyzer based power-to-methane systems: a comprehensive comparison between steam electrolysis and coelectrolysis. Appl. Energy 211, 1060-1079. doi:10.1016/j.apenergy.2017.11.050

Wang, L., Chen, M., Küngas, R., Lin, T.-E., Diethelm, S., Maréchal, F., et al. (2019). Power-to-fuels via solid-oxide electrolyzer: operating window and technoeconomics. Renew. Sustain. Energy Rev. 110, 174-187. doi:10.1016/j.rser. 2019.04.071

Wang, S., Inoishi, A., Hong, J.-E., Ju, Y.-W., Hagiwara, H., Ida, S., et al. (2013). $\mathrm{Ni}-\mathrm{Fe}$ bimetallic cathodes for intermediate temperature $\mathrm{CO}_{2}$ electrolyzers using a $\mathrm{La}_{0.9} \mathrm{Sr}_{0.1} \mathrm{Ga}_{0.8} \mathrm{Mg}_{0.2} \mathrm{O}_{3}$ electrolyte. J. Mater. Chem. A 1, 12455-12461. doi:10. $1039 / \mathrm{c} 3 \mathrm{ta} 11863 \mathrm{k}$

Wang, S., Tsuruta, H., Asanuma, M., and Ishihara, T. (2015). Ni-Fe-La(Sr)Fe(Mn) $\mathrm{O}_{3}$ as a new active cermet cathode for intermediate-temperature $\mathrm{CO}_{2}$ electrolysis using a $\mathrm{LaGaO}_{3}$-based electrolyte. Adv. Energy Mater. 5, 1401003. doi:10.1002/aenm.201401003

Wang, Y., Li, W., Ma, L., Li, W., and Liu, X. (2019). Degradation of solid oxide electrolysis cells: phenomena, mechanisms, and emerging mitigation strategies-a review. J. Mater. Sci. Technol. 55, 35-55. doi:10.1016/j.jmst.2019.07.026

Wang, Y., Liu, T., Lei, L., and Chen, F. (2017). High temperature solid oxide $\mathrm{H}_{2} \mathrm{O}$ / $\mathrm{CO}_{2}$ co-electrolysis for syngas production. Fuel Process. Technol. 161, 248-258. doi:10.1016/j.fuproc.2016.08.009

Wang, Y.-P., Gao, J.-T., Chen, W., Li, C.-X., Zhang, S.-L., Yang, G.-J., et al. (2020). Development of ScSZ electrolyte by very low pressure plasma spraying for highperformance metal-supported SOFCs. J. Therm. Spray Technol. 29, 223-231. doi:10.1007/s11666-019-00970-1

Wei, L., Zhang, J., Yu, F., Zhang, W., Meng, X., Yang, N., et al. (2019). A novel fabrication of yttria-stabilized-zirconia dense electrolyte for solid oxide fuel cells by 3D printing technique. Int. J. Hydrog. Energy 44, 6182-6191. doi:10. 1016/j.ijhydene.2019.01.071

Wei, W., and Jinlong, G. (2011). Methanation of carbon dioxide: an overview. Front. Chem. Sci. Eng. 5, 2-10. doi:10.1007/s11705-010-0528-3

Xie, K., Zhang, Y., Meng, G., and Irvine, J. T. S. (2011). Direct synthesis of methane from $\mathrm{CO}_{2} / \mathrm{H}_{2} \mathrm{O}$ in an oxygen-ion conducting solid oxide electrolyser. Energy Environ. Sci. 4, 2218-2222. doi:10.1039/c1ee01035b

Xie, Y., Xiao, J., Liu, D., Liu, J., and Yang, C. (2015). Electrolysis of carbon dioxide in a solid oxide electrolyzer with silver-gadolinium-doped ceria cathode. J. Electrochem. Soc. 162, F397-F402. doi:10.1149/2.0501504jes

$\mathrm{Xu}, \mathrm{W}$., and Scott, K. (2010). The effects of ionomer content on PEM water electrolyser membrane electrode assembly performance. Int. J. Hydrog. Energy 35, 12029-12037. doi:10.1016/j.ijhydene.2010.08.055

Yang, G., Yu, S., Kang, Z., Dohrmann, Y., Bender, G., Pivovar, B. S., et al. (2019). A novel PEMEC with 3D printed non-conductive bipolar plate for low-cost hydrogen production from water electrolysis. Energy Conv. Manag. 182, 108-116. doi:10.1016/j.enconman.2018.12.046 
Yang, L., Xie, K., Wu, L., Qin, Q., Zhang, J., Zhang, Y., et al. (2014). A composite cathode based on scandium doped titanate with enhanced electrocatalytic activity towards direct carbon dioxide electrolysis. Phys. Chem. Chem. Phys. 16, 21417-21428. doi:10.1039/c4cp02229g

Yang, X., and Irvine, J. T. S. (2008). $\left(\mathrm{La}_{0.75} \mathrm{Sr}_{0.25}\right)_{0.95} \mathrm{Mn}_{0.5} \mathrm{Cr}_{0.5} \mathrm{O}_{3}$ as the cathode of solid oxide electrolysis cells for high temperature hydrogen production from steam. J. Mater. Chem. 18, 2349-2354. doi:10.1039/b800163d

Ye, X.-F., Wen, Y. B., Yang, S. J., Lu, Y., Luo, W. H., Wen, Z. Y., et al. (2017). Study of $\mathrm{CaZr}_{0.9} \mathrm{In}_{0.1} \mathrm{O}_{3-\delta}$ based reversible solid oxide cells with tubular electrode supported structure. Int. J. Hydrog. Energy 42, 23189-23197. doi:10.1016/j. ijhydene.2017.07.195

Yentekakis, I. V., and Bebelis, S. (1992). Study of the NEMCA effect in a single-pellet catalytic reactor. J. Catal. 137, 278-283. doi:10.1016/0021-9517(92)90157-D

Yentekakis, I. V., Jiang, Y., Neophytides, S., Bebelis, S., and Vayenas, C. G. (1995). Catalysis, electrocatalysis and electrochemical promotion of the steam reforming of methane over $\mathrm{Ni}$ film and Ni-YSZ cermet anodes. Ionics 1, 491-498. doi:10.1007/bf02375296

Yentekakis, I. V., Moggridge, G., Vayenas, C., and Lambert, R. (1994). In situ controlled promotion of catalyst surfaces via NEMCA: the effect of Na on the Pt-catalyzed CO oxidation. J. Catal. 146, 292-305. doi:10.1016/0021-9517(94)90033-7

Yu, J., Men, H. J., Qu, Y. M., and Tian, N. (2020). Performance of Ni-Fe bimetal based cathode for intermediate temperature solid oxide electrolysis cell. Solid State Ion. 346, 115203. doi:10.1016/j.ssi.2019.115203

Yue, X., and Irvine, J. T. S. (2012). Alternative cathode material for $\mathrm{CO}_{2}$ reduction by high temperature solid oxide electrolysis cells. J. Electrochem. Soc. 159, F442-F448. doi:10.1149/2.040208jes

Zhang, Y.-Q., Li, J.-H., Sun, Y.-F., Hua, B., and Luo, J.-L. (2016). Highly active and redox-stable Ce-doped $\mathrm{LaSrCrFeO}$-based cathode catalyst for $\mathrm{CO}_{2}$ SOECs. ACS Appl. Mater. Interfaces 8, 6457-6463. doi:10.1021/acsami.5b11979

Zheng, Y., Chen, T., Li, Q., Wu, W., Miao, H., Xu, C., et al. (2014). Achieving 360 $\mathrm{NL} \mathrm{h}^{-1}$ hydrogen production rate through 30 -cell solid oxide electrolysis stack with LSCF-GDC composite oxygen electrode. Fuel Cells 14, 1066-1070. doi:10. 1002/fuce.201400051
Zheng, Y., Wang, J., Yu, B., Zhang, W., Chen, J., Qiao, J., et al. (2017). A review of high temperature co-electrolysis of $\mathrm{H}_{2} \mathrm{O}$ and $\mathrm{CO}_{2}$ to produce sustainable fuels using solid oxide electrolysis cells (SOECs): advanced materials and technology. Chem. Soc. Rev. 46, 1427-1463. doi:10.1039/c6cs00403b

Zhigachev, A. O., Zhigacheva, D. V., and Lyskov, N. V. (2019). Influence of yttria and ytterbia doping on phase stability and ionic conductivity of ScSZ solid electrolytes. Mater. Res. Express 6, 105534. doi:10.1088/2053-1591/ ab3ed0

Zhou, Y., Zhou, Z., Song, Y., Zhang, X., Guan, F., Lv, H., et al. (2018). Enhancing $\mathrm{CO}_{2}$ electrolysis performance with vanadium-doped perovskite cathode in solid oxide electrolysis cell. Nanomater. Energy 50, 43-51. doi:10.1016/j.nanoen. 2018.04.054

Zhu, W. Z., and Deevi, S. C. (2003a). A review on the status of anode materials for solid oxide fuel cells. Mater. Sci. Eng. 362, 228-239. doi:10.1016/s0921-5093(03) 00620-8

Zhu, W. Z., and Deevi, S. C. (2003b). Development of interconnect materials for solid oxide fuel cells. Mater. Sci. Eng. 348, 227-243. doi:10.1016/s0921-5093(02) 00736-0

Zhu, X., Li, S., Shi, Y., and Cai, N. (2019). Recent advances in elevated-temperature pressure swing adsorption for carbon capture and hydrogen production. Prog. Energy Combust. Sci. 75, 100784. doi:10.1016/j.pecs.2019.100784

Conflict of Interest: The authors declare that the research was conducted in the absence of any commercial or financial relationships that could be construed as a potential conflict of interest.

Copyright (c) 2020 Biswas, Kulkarni, Giddey and Bhattacharya. This is an openaccess article distributed under the terms of the Creative Commons Attribution License (CC BY). The use, distribution or reproduction in other forums is permitted, provided the original author(s) and the copyright owner(s) are credited and that the original publication in this journal is cited, in accordance with accepted academic practice. No use, distribution or reproduction is permitted which does not comply with these terms. 